\title{
Multitasking Kinase RIPK1 Regulates Cell Death and Inflammation
}

\author{
Kim Newton \\ Department of Physiological Chemistry, Genentech, South San Francisco, California 94080, USA \\ Correspondence: knewton@gene.com
}

Receptor-interacting serine threonine kinase 1 (RIPK1) is a widely expressed kinase that is essential for limiting inflammation in both mice and humans. Mice lacking RIPK1 die at birth from multiorgan inflammation and aberrant cell death, whereas humans lacking RIPK1 are immunodeficient and develop very early-onset inflammatory bowel disease. In contrast to complete loss of RIPK1, inhibiting the kinase activity of RIPK1 genetically or pharmacologically prevents cell death and inflammation in several mouse disease models. Indeed, small molecule inhibitors of RIPK1 are in phase I clinical trials for amyotrophic lateral sclerosis, and phase II clinical trials for psoriasis, rheumatoid arthritis, and ulcerative colitis. This review focuses on which signaling pathways use RIPK1, how activation of RIPK1 is regulated, and when activation of RIPK1 appears to be an important driver of inflammation.

$\mathrm{R}_{1}^{\mathrm{e}}$ eceptor-interacting serine threonine kinase 1 (RIPK1) was discovered more than two decades ago because of its ability to interact with the apoptosis-inducing death receptor Fas (Stanger et al. 1995). The carboxy-terminal death domain (DD) in RIPK1 (Fig. 1) binds to the intracellular DD of Fas or tumor necrosis factor receptor 1 (TNFR1) and to the DD in the adaptor proteins TRADD and FADD (Stanger et al. 1995; Hsu et al. 1996a; Chen et al. 2008; Ermolaeva et al. 2008; Pobezinskaya et al. 2008; Park et al. 2013). Another protein interaction motif in RIPK1, termed the RIP homotypic interaction motif (RHIM), mediates interactions with the RHIM-containing proteins RIPK3 (Sun et al. 2002), TRIF (also called TICAM-1) (Meylan et al. 2004; Kaiser and Offer- mann 2005), and ZBP1 (also called DAI) (Kaiser et al. 2008). Analyses of RIPK1-deficient cells indicate that RIPK1 is dispensable for Fas-induced apoptosis, but is needed in some cell types for optimal activation of nuclear factor (NF)- $\mathrm{BB}$-dependent gene transcription by TNFR1 and TLR3 (Toll-like receptor 3) (Ting et al. 1996; Kelliher et al. 1998; Meylan et al. 2004; Cusson-Hermance et al. 2005; Vanlangenakker et al. 2011; Dannappel et al.2014; Takahashi et al. 2014; Newton et al. 2016b; Van et al. 2017; Cuchet-Lourenço et al. 2018). The kinase activity of RIPK1, however, is dispensable for $\mathrm{NF}-\kappa \mathrm{B}$ signaling (Ting et al. 1996; Lee et al. 2004; Berger et al. 2014; Newton et al. 2014; Polykratis et al. 2014), instead being required for RIPK1 to engage the cell death machinery downstream from TNFR1.

Editors: Kim Newton, James M. Murphy, and Edward A. Miao

Additional Perspectives on Cell Survival and Cell Death available at www.cshperspectives.org

Copyright (C) 2020 Cold Spring Harbor Laboratory Press; all rights reserved; doi: 10.1101/cshperspect.a036368

Cite this article as Cold Spring Harb Perspect Biol 2020;12:a036368 
K. Newton

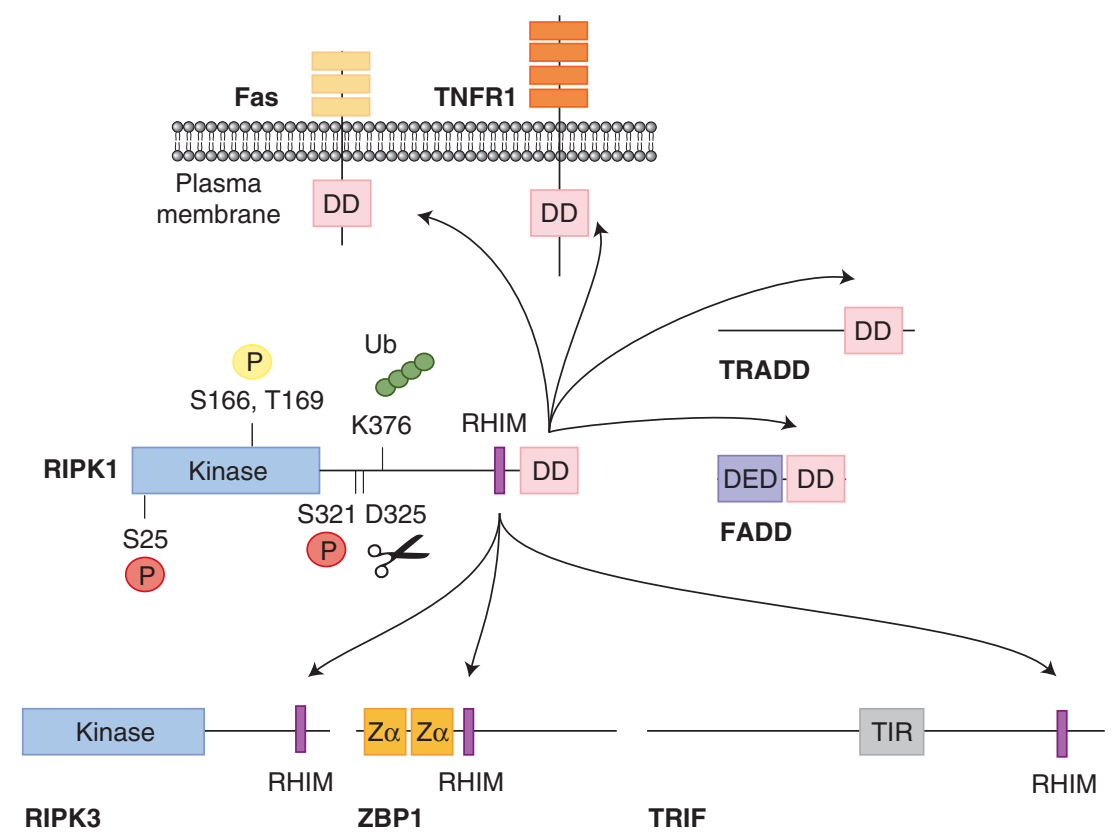

Figure 1. Domain organization and protein interactions of receptor-interacting serine threonine kinase 1 (RIPK1). RIPK1 has an amino-terminal kinase domain and carboxy-terminal RIP homotypic interaction motif (RHIM) and death domain (DD) motif. The RHIM and DD mediate interactions with other RHIM- or DDcontaining proteins. Dimerization of RIPK1 via its DD promotes autophosphorylation of the kinase domain on Ser166. Thr169 in mouse RIPK1 is autophosphorylated as well, but this residue is not conserved in human RIPK1. Posttranslational modifications of RIPK1 that appear to limit activation of the kinase include ubiquitination (Ub) on mouse Lys376 (human Lys377), cleavage after mouse Asp325 (human Asp324) by caspase-8, phosphorylation on mouse Ser321 (human Ser320) by MK2, and phosphorylation on Ser25 by IкB kinase (IKK). DED, death effector domain; TIR, Toll/interleukin-1 receptor domain; Z $\alpha$, Z-DNA-binding domain.

\section{SIGNALING PATHWAYS THAT USE RIPK1}

\section{TNFR1 Signaling}

RIPK1 is a component of what is termed TNFR1 complex I (Fig. 2; Micheau and Tschopp 2003). Ligated TNFR1 recruits TRADD and RIPK1, with TRADD serving as an adaptor for TRAF2 (Hsu et al. 1996b), which in turn binds to the E3 ubiquitin ligases cIAP1 and cIAP2 (Shu et al. 1996; Vince et al. 2009). The cellular inhibitors of apoptosis proteins (cIAPs) ubiquitinate RIPK1, themselves, and possibly other components of complex I (Bertrand et al. 2008; Mahoney et al. 2008; Varfolomeev et al. 2008), forming polyubiquitin chains in which the carboxy-terminal glycine of one ubiquitin is conjugated predominantly to Lys 11 or Lys63 of a second ubiquitin (Dynek et al. 2010). This polyubiquitin recruits several ubiquitin-binding proteins, including TAB2 and TAB3, adaptors for the kinase TAK1 (Cheung et al. 2004; Kanayama et al. 2004); NEMO, the regulatory subunit of the ca-

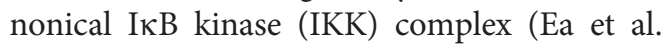
2006; Wu et al. 2006); and HOIL-1, HOIP, and Sharpin, which comprise the E3 ubiquitin ligase linear ubiquitin assembly complex (LUBAC) (Haas et al. 2009). LUBAC then modifies TNFR1, TRADD, RIPK1, and NEMO with Met1-linked polyubiquitin (Gerlach et al. 2011; Tokunaga et al. 2011; Draber et al. 2015), which further stabilizes complex I through interactions with NEMO (Lo et al. 2009; Rahighi et al. 2009). Hybrid polyubiquitin chains on RIPK1 containing both Lys63 and Met1 linkages are proposed to position TAK1 next to the IKK complex (Emmerich et al. 2016), so that TAK1 can phosphor- 
RIPK1 Regulates Cell Death and Inflammation

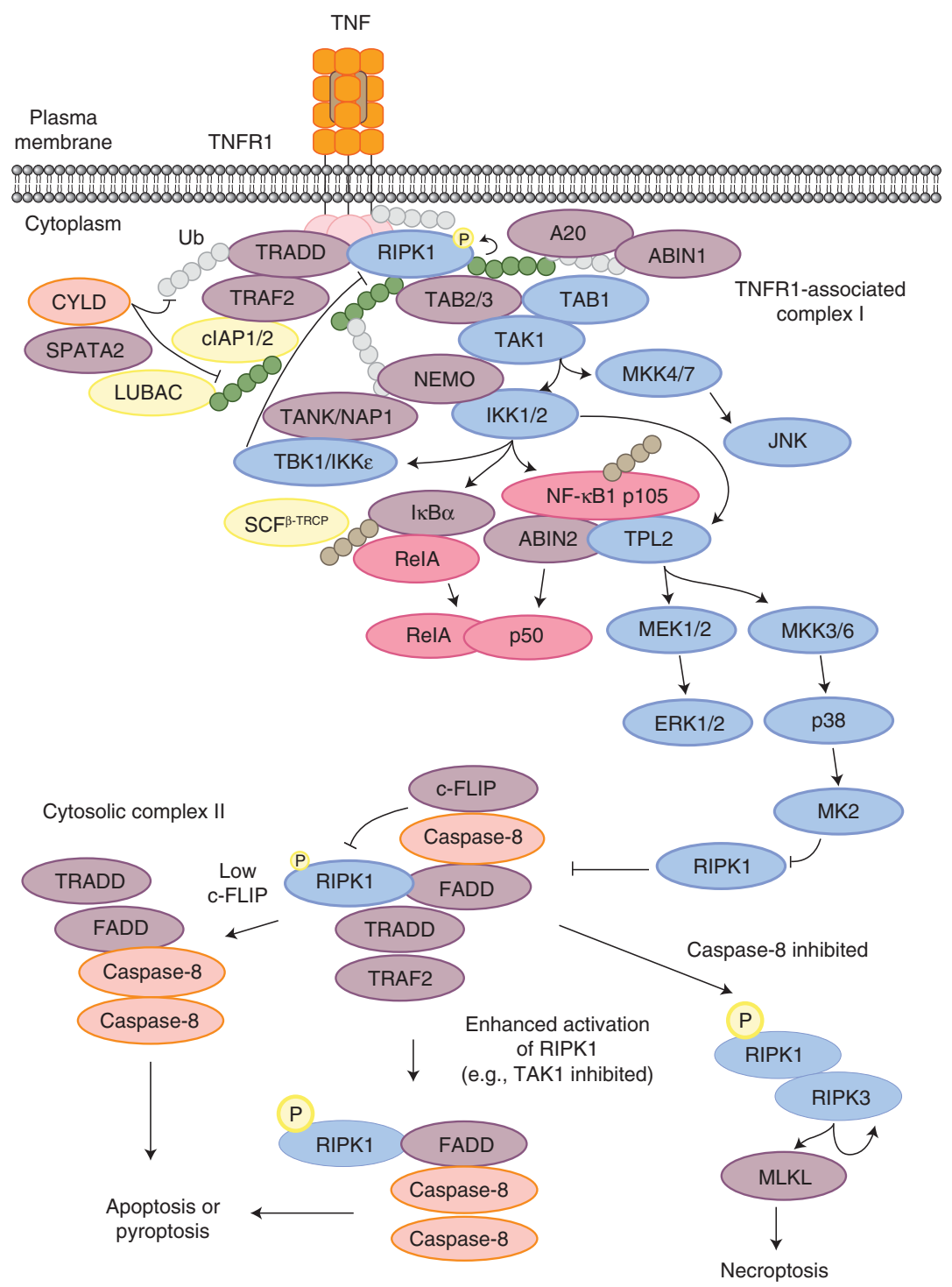

Figure 2. Receptor-interacting serine threonine kinase 1 (RIPK1) is a component of tumor necrosis factor receptor 1 (TNFR1) complex I and complex II. Binding of tumor necrosis factor (TNF) to TNFR1 triggers assembly of complex I, which activates nuclear factor (NF)- $\kappa B$-dependent gene transcription and the mitogenactivated protein kinases ERK, JNK, and p38. Autophosphorylation of RIPK1 is detected in complex I in mouse cells, but it is unclear whether this is also true in human cells. Activation of the kinases TAK1, IKK, and TBK1/ IKK $\varepsilon$ in complex I limits activation of RIPK1 and suppresses formation of cytosolic complex II. The translational inhibitor cycloheximide is thought to promote TNF-induced apoptosis by depleting c-FLIP from complex II, which facilitates the emergence of caspase- 8 homodimers that drive cell death. Inhibitors of RIPK1 do not block this death, but they do prevent caspase-8-dependent cell death that is driven by perturbations of complex I that enhance activation of RIPK1, such as cIAP1/2 deficiency or inhibition of the IKK complex. The kinase activity of RIPK1 is also needed for RIPK3/MLKL-dependent necroptosis when the proteolytic activity of caspase-8/c-FLIP heterodimers is inhibited. Inhibitory phosphorylation of cytosolic RIPK1 by MK2 is thought to limit recruitment of additional RIPK1 into complex II. Kinases are colored blue, ubiquitin ligases are yellow, proteases are orange, adaptor proteins are purple, and transcription factors are pink. Met1-linked polyubiquitin (Ub) is colored gray, K63- or K11-linked chains are green, and K48-linked chains are brown. 
ylate and activate the IKK2 catalytic subunit (Zhang et al. 2014). The IKK complex phosphorylates the NF- $\kappa \mathrm{B}$ inhibitory proteins NF$\kappa \mathrm{B} 1 / \mathrm{p} 105$ and $\mathrm{I} \kappa \mathrm{B} \alpha$, leading to their ubiquitination and proteasomal processing (Zhang et al. 2017). Degradation of $I \kappa B \alpha$ and processing of NF- $\kappa \mathrm{B} 1 / \mathrm{p} 105$ to $\mathrm{NF}-\kappa \mathrm{B} 1 / \mathrm{p} 50$ liberates NF- $\kappa \mathrm{B}$ dimers composed largely of RelA and NF- $\kappa \mathrm{B} 1 /$ p50. These dimers enter the nucleus and promote expression of their target genes. Processing of NF- $\mathrm{KB} 1 / \mathrm{p} 105$ also liberates the kinase TPL2 to stimulate the MEK-ERK and MKK3/6-p38 kinase cascades (Eliopoulos et al. 2003; Pattison et al. 2016). Besides activating the IKK complex, TAK1 also stimulates the MKK7-JNK kinase cascade (Tournier et al. 2001; Shim et al. 2005).

NEMO and LUBAC in complex I are also needed to recruit TANK and NAP1, the ubiquitin-binding adaptors for the kinases TBK1 and IKKe (Lafont et al. 2018; Xu et al. 2018b). Phosphorylation of TBK1 and IKKe by the canonical IKK complex stimulates their activation (Clark et al. 2011). The major function of TBK1 and $\mathrm{IKK} \varepsilon$ is to suppress the activation of RIPK 1 and prevent TNF-induced cell death. Accordingly, lethal apoptosis in TBK1-deficient mouse embryos is prevented by TNFR1 deficiency (Bonnard et al. 2000), TNF deficiency (Matsui et al. 2006), or catalytically inactive RIPK1 (Xu et al. 2018b). TBK1 is proposed to phosphorylate RIPK1 directly on multiple residues to suppress RIPK1 autophosphorylation (Lafont et al. 2018; $\mathrm{Xu}$ et al. 2018b). TAK1 also suppresses RIPK1 activation after TNF treatment and this is independent of its role in activating NF- $\kappa \mathrm{B}$ (Vanlangenakker et al. 2011; Dondelinger et al. 2013; Lamothe et al. 2013). Whether TAK1 phosphorylates RIPK1 directly is controversial (Dondelinger et al. 2015; Geng et al. 2017), but suppression of RIPK1 activation by TAK1-dependent IKK and MK2 activation is well documented (Dondelinger et al. 2015; Jaco et al. 2017; Menon et al. 2017).

IKK appears to phosphorylate RIPK1 in complex I directly on Ser25 (Dondelinger et al. 2015, 2019), but it could also influence phosphorylation of RIPK1 indirectly via the activation of TBK1 (Clark et al. 2011; Lafont et al. 2018; $\mathrm{Xu}$ et al. 2018b). Consistent with multiple IKK- dependent phosphorylation events restraining activation of RIPK1, mutation of RIPK1 Ser25 to Ala does not mimic inhibition of IKK (Dondelinger et al. 2019). MK2 is activated by the TAK1-MKK3/6-p38 kinase cascade and it phosphorylates cytosolic RIPK1 on murine Ser321/human Ser320 and possibly other residues (Jaco et al. 2017; Menon et al. 2017). Consistent with IKK and MK2 inhibiting RIPK1 by distinct mechanisms, combined IKK and MK2 inhibition sensitizes cells to TNF more than inhibiting just one of the kinases (Menon et al. 2017).

Genetic studies in mice support the idea that NEMO is critical for inhibiting the activation of RIPK1 and does so independent of its role in promoting NF- $\kappa \mathrm{B}$-dependent gene transcription. For example, Nemo deletion in intestinal epithelial cells causes colitis that is prevented by catalytically inactive RIPK1, whereas colitis is not induced by the combined loss of RelA, RelB, and c-Rel, the three NF- $\kappa \mathrm{B}$ subunits with transactivation domains (Vlantis et al. 2016). Similarly, Nemo deletion in hepatocytes causes hepatocellular carcinoma that is prevented by catalytically inactive RIPK1, whereas hepatocellular carcinoma is not observed on deletion of RelA, RelB, and $c$-Rel (Kondylis et al. 2015). Although these experiments highlight an NF- $\mathrm{KB}$ independent mechanism for RIPK1 inactivation by NEMO, perhaps via the combined actions of $\mathrm{IKK} \alpha / \beta, \mathrm{TBK} 1$, and $\mathrm{IKK} \varepsilon$, there is also evidence for NF- $\kappa \mathrm{B}$-dependent inactivation of RIPK1. For example, mice lacking either NEMO or RelA die during embryogenesis, but survive to birth if they express catalytically inactive RIPK1 (Vlantis et al. 2016; Xu et al. 2018a). Several prosurvival proteins that could impact RIPK1 activation are encoded by NF- $\mathrm{BB}$ target genes, including the cIAPs (Wang et al. 1998), X-linked inhibitor of apoptosis protein (XIAP) (Stehlik et al. 1998), A20 (Krikos et al. 1992), and cellular FLICE inhibitory protein (c-FLIP) (Kreuz et al. 2001).

The cIAPs contribute to the assembly of TNFR1 complex I as described above, but may also limit activation of RIPK1 by modifying RIPK1 with Lys48-linked polyubiquitin that targets it for proteasomal degradation (Varfolo- 
RIPK1 Regulates Cell Death and Inflammation

meev et al. 2008; Dynek et al. 2010; Annibaldi et al. 2018). Genetic studies in mice implicate XIAP and A20 in the suppression of RIPK1 activation (Wong et al. 2014; Onizawa et al. 2015; Newton et al. 2016a; Kattah et al. 2018; Rijal et al. 2018), but the underlying biochemical mechanism in each case is still being elucidated. The binding of A20 to Met1-linked polyubiquitin in TNFR1 complex I appears to be critical to limiting TNF-induced cell death (Draber et al. 2015; Yamaguchi and Yamaguchi 2015; Polykratis et al. 2019). A20 also appears to act in concert with the ubiquitin-binding protein ABIN-1 (Oshima et al. 2009; Dziedzic et al. 2018; Kattah et al. 2018). c-FLIP is the catalyti- cally inactive paralog of the cysteine protease caspase-8 (previously called FLICE) (Irmler et al. 1997) and is discussed in more detail in the section on activation of RIPK1.

\section{TLR3 and TLR4 Signaling}

RIPK1 recruitment to TLR3, which detects double-stranded RNA (dsRNA) in the endosomal compartment, or to TLR4, which detects bacterial lipopolysaccharide (LPS) at the cell surface and is then endocytosed, is mediated by the adaptor TRIF (Fig. 3; Meylan et al. 2004). TRIF binding to RIPK1 and to the E3 ubiquitin ligase TRAF6 promotes TAK1- and LUBAC-depen-

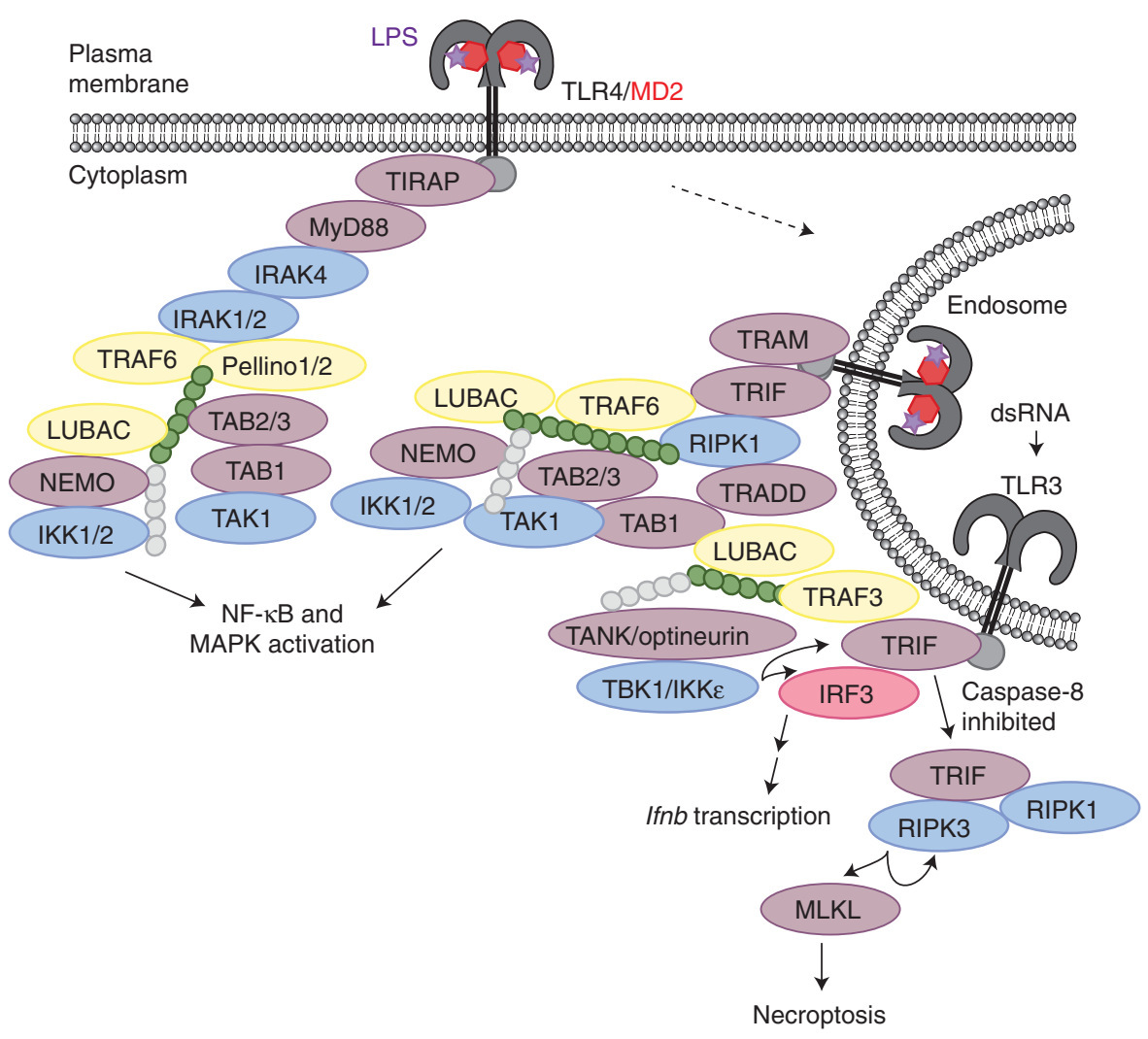

Figure 3. Receptor-interacting serine threonine kinase 1 (RIPK1) mediates TRIF-dependent NF- $\kappa \mathrm{B}$ and mitogen-activated protein kinase (MAPK) activation by TLR3 and TLR4. The adaptor protein TRIF has a RHIM that recruits RIPK1 to TLR3 and TLR4 signaling complexes on endosomes. RIPK1 contributes to the activation of TAK1 and the IKK complex, but appears dispensable for TRIF-dependent activation of IRF3 and the expression of type I interferons, as well as TRIF-dependent activation of RIPK3/MLKL-dependent necroptosis. Inhibited RIPK1 can, however, block TRIF-dependent necroptosis. Both TLR3 and TLR4 trigger these different TRIFdependent signals. RIPK1 is dispensable for TLR4 signaling via the adaptor MyD88. 
K. Newton

dent IKKactivation that leads to the expression of proinflammatory genes (Jiang et al. 2003, 2004; Sato et al. 2003; Meylan et al. 2004; CussonHermance et al. 2005; Zinngrebe et al. 2016; Bakshi et al. 2017). Presumably, TRAF6 builds Lys63-linked polyubiquitin chains on RIPK1 that recruit TAK1, IKK, and LUBAC, but this has not been confirmed experimentally. Another E3 ubiquitin ligase, Pellino1, was implicated in TLR3-induced RIPK1 ubiquitination and IKK activation (Chang et al. 2009), but results obtained with cells expressing ligase inactive Pellino1 indicate that the E3 activity of Pellino1 is not required for either signaling event (Enesa et al. 2012). The adaptor TRADD, perhaps through binding to the DD of RIPK1, contributes to TLR3-induced NF- $\kappa B$ and mitogen-activated protein kinase (MAPK) activation in fibroblasts, but appears less critical in myeloid cells (Chen et al. 2008; Ermolaeva et al. 2008; Pobezinskaya et al. 2008). TLR3 and TLR4 also use TRIF to engage TANK- or optineurin-containing TBK1 complexes that promote activation of the transcription factor IRF3 and expression of Interferon beta (Ifnb) (Fitzgerald et al. 2003; Hemmi et al. 2004; McWhirter et al. 2004; Perry et al. 2004; Liu et al. 2015; Bakshi et al. 2017). However, neither TRAF6 nor RIPK1 is essential for TRIF-induced IFN- $\beta$ expression (Sato et al. 2003; Jiang et al. 2004; Meylan et al. 2004; Cusson-Hermance et al. 2005).

\section{Other Signaling Pathways Involved in} Pathogen Defense

Recent genetic studies in mice have illuminated a role for RIPK1 in promoting proinflammatory gene expression during development, although the nature of the upstream activating signal(s) is unclear. For example, RIPK1 causes modest proinflammatory gene expression in mouse embryos lacking caspase- 8 and the kinase RIPK3 (Kang et al. 2018). This aberrant gene expression is greatly exacerbated if LUBAC is compromised (Heger et al. 2018; Peltzer et al. 2018). Indeed, mice lacking caspase- 8 and RIPK3 are viable (Kaiser et al. 2011; Oberst et al. 2011), whereas mice lacking caspase-8, RIPK3, and either HOIL-1 or Sharpin die in the perinatal pe- riod (Rickard et al. 2014a; Peltzer et al. 2018). Mice lacking caspase-8, RIPK3, and OTULIN activity also die in the perinatal period, OTULIN being a deubiquitinating enzyme that preserves LUBAC activity (Heger et al. 2018). Depending on the mouse model, cytokine and chemokine expression is normalized by either complete loss of Ripk 1 (Peltzer et al. 2018) or by loss of a single allele of Ripk1 (Heger et al. 2018), and perinatal lethality is either delayed (Peltzer et al. 2018) or prevented (Heger et al. 2018). A small molecule inhibitor of RIPK1 was unable to rescue mice lacking caspase-8, RIPK3, and HOIL-1 (Peltzer et al. 2018), so the kinase activity of RIPK1 may be dispensable for this proinflammatory gene expression.

IFN- $\beta$ and IFN-inducible chemokines such as CXCL10 were expressed in a RIPK1-dependent manner in both of the aforementioned studies (Heger et al. 2018; Peltzer et al. 2018). Although RIPK1 is dispensable for TLR3- or TLR4-induced IFN- $\beta$ production (Meylan et al. 2004; Cusson-Hermance et al. 2005), RIPK1, TRADD, and FADD are implicated in IFN- $\beta$ production triggered by cytosolic RLRs (RIGI-like receptors) (Balachandran et al. 2004; Michallet et al. 2008; Rajput et al. 2011). RLRs RIG-I and MDA5 recognize dsRNA and engage the mitochondrial antiviral signaling (MAVS) protein, which in turn recruits TRAF2, TRAF5, and TRAF6 to promote NEMO-dependent activation of IKK and TBK1 (Liu et al. 2013). Precisely how RIPK1 fits into this signaling pathway and whether its kinase activity is needed is unclear. It is tempting to speculate that aberrant RIPK1-dependent IFN- $\beta$ signaling drives the lethal phenotype of mice lacking LUBAC activity, RIPK3 and caspase-8, but exploring this further will require genetic crosses that eliminate the IFN- $\alpha / \beta$ receptor or MAVS.

\section{ACTIVATION OF RIPK1 PROMOTES CELL DEATH}

The enzymatic activity of RIPK1 was first shown to promote cell death in Jurkat $\mathrm{T}$ cells treated with FasL (Fas ligand) and the pan-caspase inhibitor Z-VAD-FMK (Holler et al. 2000). Fasinduced apoptosis mediated by the adaptor 
FADD and caspase- 8 was blocked, but now the cells died a necrotic death requiring the kinase activity of RIPK1. Jurkat $\mathrm{T}$ cells treated with TNF, CHX (cycloheximide), and Z-VAD-FMK also died in a manner requiring the kinase activity of RIPK1 (Holler et al. 2000). Although Jurkat $\mathrm{T}$ cells (and many other cell types) are not killed by TNF alone, addition of the translational inhibitor CHX is thought to promote TNFR1-dependent apoptosis by eliminating the labile protein c-FLIP (Micheau and Tschopp 2003). Caspase- 8 then forms homodimers rather than caspase-8/c-FLIP heterodimers in a secondary, cytosolic complex II that also contains FADD, TRADD, TRAF2, and RIPK1 (Fig. 2). Activation of caspase- 8 within complex II initiates the apoptotic caspase cascade that dismantles the cell (Micheau and Tschopp 2003). Note that the kinase activity of RIPK1 is dispensable for apoptosis induced by TNF and cycloheximide (Wang et al. 2008). It is only required when Z-VAD-FMK is incorporated into the death stimulus (Holler et al. 2000).

Z-VAD-FMK and other pan-caspase inhibitors block caspase-8-dependent apoptosis, but cell death is not prevented if cells express the kinase RIPK3 and the pseudokinase MLKL (mixed lineage kinase domain-like) (Cho et al. 2009; He et al. 2009; Zhang et al. 2009; Sun et al. 2012; Zhao et al. 2012; Murphy et al. 2013; Wu et al. 2013). Instead of dying by apoptosis, cells unleash a caspase-independent death program termed necroptosis (Degterev et al. 2005). The enzymatic activity of RIPK1, which is essential for TNFR1-induced necroptosis (Holler et al. 2000), is required for interactions between RIPK1 and RIPK3 in complex II (Cho et al. 2009; He et al. 2009). The only known substrate of RIPK1 is itself, with Ser166 and other residues within the kinase domain, being autophosphorylated in trans (Ting et al. 1996; Degterev et al. 2008). In primary mouse embryo fibroblasts (MEFs), autophosphorylated RIPK1 is detected in TNFR1 complex I within minutes of TNF stimulation (Newton et al. 2016b). Dimerization of RIPK1 via its DD promotes autophosphorylation (Meng et al. 2018), whereas the RHIM in RIPK1 is dispensable (Newton et al. 2016b). Autophosphorylation may induce con- formational changes that expose the RHIM of RIPK1 for interactions with the RHIM of RIPK3. RHIM-RHIM interactions between RIPK1 and RIPK3 in complex II are required for oligomerization and autophosphorylation of RIPK3 (Cho et al. 2009; He et al. 2009; Sun et al. 2012; Chen et al. 2013; Wu et al. 2014; Mompeán et al. 2018). Autophosphorylated RIPK3 then phosphorylates the carboxy-terminal pseudokinase domain of MLKL (Sun et al. 2012; Murphy et al. 2013; Xie et al. 2013; Rodriguez et al. 2016) and conformational changes in MLKL trigger its translocation to membranes and cell lysis (Fig. 2; Cai et al. 2014; Hildebrand et al. 2014; Su et al. 2014; Wang et al. 2014; Petrie et al. 2018).

Necroptosis is considered a host-defense mechanism for eliminating cells infected with viruses that encode inhibitors of caspase-8-dependent apoptosis (Chan et al. 2003; Cho et al. 2009; Guo et al. 2015). Death ligands such as FasL, TRAIL, and TNF are not the only triggers of necroptosis. Provided caspase- 8 is inhibited, RIPK3-dependent necroptosis can also be triggered by TLRs, RIG-I, the cytosolic DNA sensor cGAS, the RHIM-containing protein ZBP1, or the T-cell receptor (Ch'en et al. 2008, 2011; He et al. 2011; Upton et al. 2012; Kaiser et al. 2013; Schock et al. 2017; Brault et al. 2018). It is unclear how the T-cell receptor engages the necroptosis machinery, but TLRs that signal using the adaptor MyD88, RIG-I, and cGAS all appear to induce necroptosis via autocrine TNF production (Kaiser et al. 2013; Brault et al. 2018). In contrast, TLR3 and TLR4 can engage RIPK3 directly via TRIF (Fig. 3; He et al. 2011; Kaiser et al. 2013; Buchrieser et al. 2018). ZBP1, which appears to sense certain virus infections by binding to viral RNA transcripts (Thapa et al. 2016; Maelfait et al. 2017; Guo et al. 2018), can also engage RIPK3 (Upton et al. 2012; Lin et al. 2016; Newton et al. 2016b; Nogusa et al. 2016). ZBP1 and TRIF can both activate RIPK3 in the absence of RIPK1 (Lin et al. 2016; Newton et al. 2016b), so it is interesting that inhibited RIPK1 blocks TLR3-induced necroptosis in macrophages (He et al. 2011; Kaiser et al. 2013; McComb et al. 2014). The ability of RIPK1 to suppress RIPK3 activation by ZBP1 and TRIF is 
K. Newton

discussed further in the section on the prosurvival function of RIPK1.

Many studies now indicate that activation of RIPK1 is not solely associated with necroptosis. For example, TNF induces excessive activation of RIPK1 in cells lacking cIAP1 and cIAP2 (Wang et al. 2008; Moulin et al. 2012; Dondelinger et al. 2013; Polykratis et al. 2014), TAK1 (Dondelinger et al. 2013; Lamothe et al. 2013), LUBAC (Berger et al. 2014; Kumari et al. 2014; Peltzer et al. 2014, 2018; Rickard et al. 2014a; Heger et al. 2018), IKK (Dondelinger et al. 2015), or ABIN-1 (Dziedzic et al. 2018; Kattah et al. 2018), and this results in caspase-8-dependent cell death. Active RIPK1 promotes the assembly of complex II, using its DD to interact with FADD. Activation of caspase-8 via FADD typically engages the apoptotic machinery, but a recent study showed that macrophages exposed to TNF and TAK1 inhibitor display a lytic form of cell death termed pyroptosis (Orning et al. 2018). In this setting, caspase- 8 cleaves the protein gasdermin D (GSDMD) to produce an amino-terminal fragment that forms pores in the plasma membrane. Consequently, cell death that is prevented by RIPK1 inhibitors, such as Nec-1s (Degterev et al. 2008), could be caused by apoptosis, pyroptosis, or necroptosis. The type of cell death will depend on the activity of caspase- 8 and the substrates that are available to it. Pyroptosis mediated by gasdermin pores is more rapid than apoptosis (Wang et al. 2017b), so it might be the dominant form of cell death in cells expressing both caspase- 8 and GSDMD.

\section{CASPASE-8 SUPPRESSES CELL DEATH BY CLEAVING RIPK1}

Pan-caspase inhibitors such as Z-VAD-FMK are used to induce necroptosis in cultured cells, but exactly how inhibition of caspase- 8 promotes activation of RIPK3 is not well understood. In apoptotic cells, caspase-8 cleaves RIPK1 after murine Asp325/human Asp324 (Lin et al. 1999) and this might limit interactions between RIPK1 and RIPK3 that would lead to necroptosis. It should be noted, however, that caspase- 8 can suppress necroptosis even in the absence of apoptosis. For example, inhibition of caspase- 8 with Z-VAD-FMK in mouse bone marrow-derived macrophages is sufficient to convert TNF from a nonlethal stimulus into a lethal necroptosis stimulus (Newton et al. 2016b). Indeed, necroptosis suppression appears to be mediated by the proteolytic activity of caspase-8/c-FLIP heterodimers rather than autoprocessed caspase-8 homodimers (Kang et al. 2008; Oberst et al. 2011). Consistent with c-FLIP suppressing both caspase-8-dependent apoptosis and RIPK3-dependent necroptosis, mice lacking cFLIP die around embryonic day 11 (E11) (Yeh et al. 2000), but are viable if they also lack caspase- 8 and RIPK3 (Dillon et al. 2012). Mice lacking caspase-8 or FADD also die around E11 (Varfolomeev et al. 1998; Yeh et al. 1998), but only need to lose RIPK3 or MLKL to be viable (Kaiser et al. 2011; Oberst et al. 2011; AlvarezDiaz et al. 2016; Zhang et al. 2016). TNFR1- and RIPK1-dependent necroptosis, particularly in endothelial cells, appears to drive the lethal phenotype of FADD- or caspase-8-deficient embryos at E11 (Kang et al. 2004; Zhang et al. 2011; Dillon et al. 2014; Kaiser et al. 2014; Rickard et al. 2014b), although embryos lacking caspase- 8 and TNFR1, or FADD and RIPK1, or caspase-8 and RIPK1 still succumb later in development (Zhang et al. 2011; Dillon et al. 2014; Kaiser et al. 2014; Rickard et al. 2014b) because ZBP1 and TRIF then drive RIPK3-dependent necroptosis (Newton et al. 2016b).

What do caspase-8/c-FLIP heterodimers cleave to prevent necroptosis? In mice, mutation of RIPK1 Asp325 to Ala to prevent RIPK1 cleavage by caspase- 8 is lethal around E11 (Zhang et al. 2019a), which is what one would expect if RIPK1 has to be cleaved to prevent necroptosis. However, lethality is prevented by the combined loss of FADD and RIPK3, but not by the loss of RIPK3 alone (Zhang et al. 2019a). Therefore, RIPK1 D325A appears to trigger apoptosis mediated by FADD and caspase- 8 , rather than necroptosis. Perhaps transient assembly of TNFR1 complex II is sustained in the absence of RIPK1 cleavage and, as a consequence, the capacity of c-FLIP to curb caspase-8-dependent apoptosis is overwhelmed.

Caspase-8 can also cleave the deubiquitinating enzyme CYLD after Asp215 (O’Donnell 
RIPK1 Regulates Cell Death and Inflammation

et al. 2011). CYLD is recruited to TNFR1 complex I by its adaptor SPATA2, which binds to HOIP (Elliott et al. 2016; Kupka et al. 2016; Schlicher et al. 2016; Wagner et al. 2016). Cleavage of Lys63- and Met1-linked polyubiquitin by CYLD then promotes complex II assembly and cell death (Hitomi et al. 2008; Wang et al. 2008; Moquin et al. 2013; Draber et al. 2015; Callow et al. 2018). Genetic studies in mice are consistent with CYLD facilitating necroptosis. For example, catalytically inactive CYLD delays RIPK3-dependent skin lesions when FADD is deleted from keratinocytes (Bonnet et al. 2011), and prevents some, but not all, RIPK3-dependent lesions when FADD is deleted from intestinal epithelial cells (Welz et al. 2011). Nonetheless, cleavage of CYLD after Asp215 does not appear to be a critical function of caspase- 8 because mutation of CYLD Asp215 to Ala is not sufficient for TNF-induced necroptosis in macrophages (Legarda et al. 2016).

\section{CELL DEATH-INDEPENDENT OUTCOMES OF RIPK1 ACTIVATION}

Activation of RIPK1 may also promote inflammation independent of its role in triggering cell death, although the underlying mechanistic details are less clear. For example, mice expressing catalytically inactive RIPK1 show increased paresis after infection with Zika virus (Daniels et al. 2019) and increased mortality after infection with West Nile virus (Daniels et al. 2017). These phenotypes appear cell death-independent because they are not observed in mice lacking both caspase- 8 and MLKL. Instead, activation of RIPK1 in neurons appears to be important for inducing antiviral transcriptional programs (Daniels et al. 2019). In a similar vein, MLKL-deficient mouse macrophages treated with LPS plus Z-VAD-FMK up-regulate proinflammatory genes such as Tnf and Ifnb without dying by necroptosis, and this transcriptional response is blocked by inhibitors of RIPK1 (Najjar et al. 2016; Saleh et al. 2017). In another study, RIPK1 inhibitor Nec-1 blocked transcription of Tnf in RIPK3-deficient macrophages treated with compound A, a pan-IAP antagonist (Wong et al. 2014). Collectively, these data suggest that inhibitors of RIPK1 could block several proinflammatory mechanisms, rather than just proinflammatory cell death.

\section{THE PROSURVIVAL FUNCTION OF RIPK1}

Despite being required for TNF-induced necroptosis, and in some contexts, TNF-induced apoptosis or pyroptosis, there is compelling genetic evidence that RIPK1 can also suppress caspase-8-dependent apoptosis and MLKL-dependent necroptosis (Fig. 4; Dannappel et al. 2014; Dillon et al. 2014; Kaiser et al. 2014; Orozco et al. 2014; Rickard et al. 2014b; Roderick et al. 2014; Takahashi et al. 2014; Raju et al. 2018). For example, mice lacking RIPK1 die around birth (Kelliher et al. 1998), unless both the apoptotic and necroptotic death programs are disabled by the loss of caspase- 8 and RIPK3 (Dillon et al. 2014; Kaiser et al. 2014; Rickard et al. 2014b). RIPK1 may suppress caspase-8-dependent cell death by preventing interactions between TRADD and FADD (Anderton et al. 2019), but it is unclear whether this is because the DD of RIPK1 binds to and sequesters TRADD or FADD. Mice expressing RIPK1 with a K584R DD mutation are viable (Meng et al. 2018), but the role of the DD in the prosurvival function of RIPK1 remains ambiguous because this mutation is unlikely to block all DD interactions. For example, although human RIPK1 with the equivalent K599R mutation is unable to form homodimers, it can still interact with TNFR1, FADD, and TRADD (Meng et al. 2018). RIPK1 that completely lacks the carboxy-terminal DD is expressed poorly in mice (K Newton and VM Dixit, unpubl.), so lethality in the homozygous state cannot be attributed to a prosurvival function of the DD specifically.

Mutating the RHIM of RIPK1 causes ZBP1/ RIPK3/MLKL-dependent perinatal lethality in mice without compromising the expression of RIPK1 (Lin et al. 2016; Newton et al. 2016b). Therefore, the RIPK1 RHIM is a critical brake on ZBP1-induced necroptosis. In macrophages, the RIPK1 RHIM also prevents TRIF from activating RIPK3 (Newton et al. 2016b). Biochemical evidence for RIPK1 simply sequestering the 
K. Newton

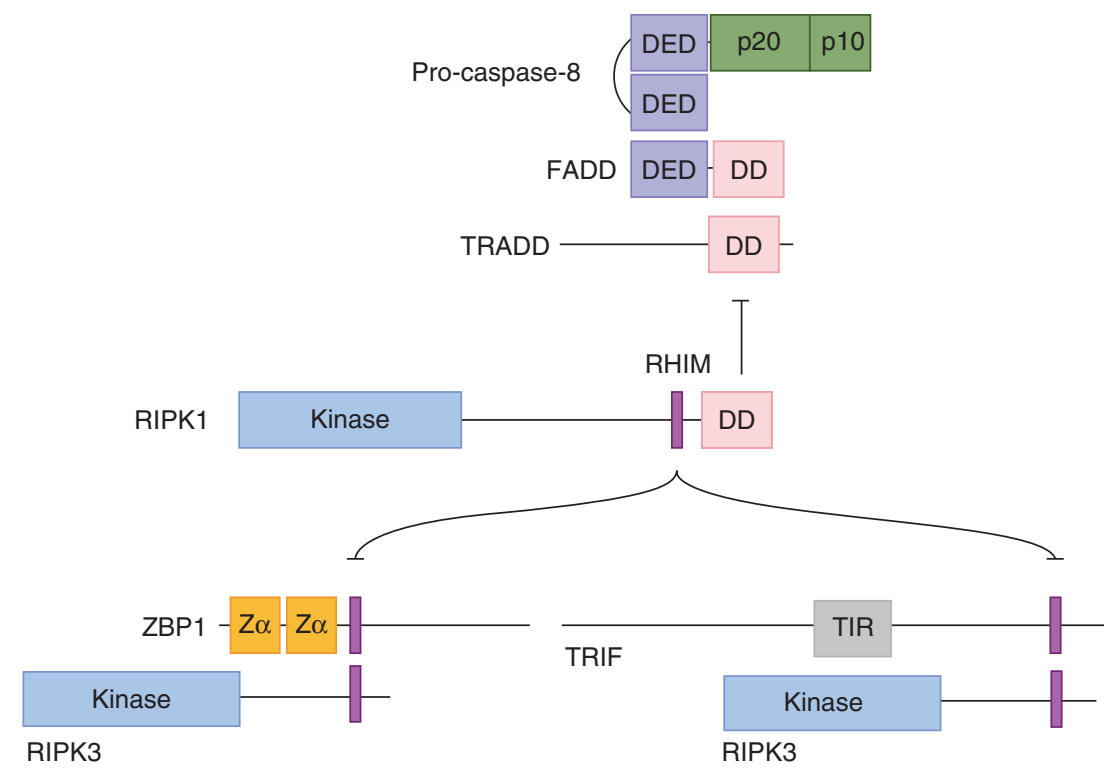

Figure 4. Model for the prosurvival function of receptor-interacting serine threonine kinase 1 (RIPK1). Mouse RIPK1 uses its RIP homotypic interaction motif (RHIM) to suppress activation of RIPK3-dependent necroptosis by TRIF and ZBP1. RIPK1 also suppresses FADD/caspase-8-dependent cell death, but whether this is dependent on the death domain (DD) of RIPK1 is unclear. The nature of the RHIM-dependent interactions that allow RIPK1 to limit activation of RIPK3 are also unknown.

other RHIM-containing proteins has proven elusive, prompting speculation that transient RHIM-RHIM interactions might hold RIPK3 in check. TNF-induced activation of MAPKs and NF- $\mathrm{KB}$ is normal in cells expressing RHIM mutant RIPK1 (Lin et al. 2016; Newton et al. 2016b), so the perinatal lethality of RHIM mutant RIPK1 mice does not appear to be caused by impaired expression of prosurvival factors such as c-FLIP, A20, and c-IAP1/2. ZBP1/RIPK3/ MLKL-dependent inflammation is detected as early as E17.5 in RIPK1 RHIM mutant mice (Newton et al. 2016b), so there is also the question of what ZBP1 might be sensing in utero. Given that interactions between RIPK1 and other RHIM-containing proteins are usually not detected without a stimulus, identification of the ZBP1 ligand is probably key to unraveling how RIPK1 prevents ZBP1-induced necroptosis.

The enzymatic activity of RIPK1 is dispensable for the prosurvival function of RIPK1 because mice expressing catalytically inactive RIPK1 are viable (Kaiser et al. 2014; Newton et al. 2014; Polykratis et al. 2014). It may be that inhibition of RIPK1 enzymatic activity prevents cell death in certain contexts (e.g., necroptosis induced by TLR3 agonist plus zVAD-FMK) by enforcing this ill-defined brake function of RIPK1. Therefore, a better understanding of how RIPK1 suppresses activation of caspase- 8 and RIPK3 might help identify disease settings in which inhibitors of RIPK1 could offer a therapeutic benefit.

In humans, RIPK1 deficiency is associated with immunodeficiency, very early-onset inflammatory bowel disease, and arthritis $(\mathrm{Cu}-$ chet-Lourenço et al 2018; Li et al 2019). Although inflammation appears less widespread than in RIPK1-deficient mice, cells from RIPK1-deficient patients display similar defects in signaling to cells from RIPK1-deficient mice. For example, fibroblasts fail to activate MAPK and NF- $\kappa \mathrm{B}$ signaling normally in response to TNF or a TLR3 agonist, and they show increased cell death. Blood cells treated with LPS also show impaired cytokine production (Cuchet-Lourenço et al. 2018). Therefore, aberrant cell death 
owing to RIPK1 deficiency might drive disease in humans as well as mice.

\section{PRECLINICAL DISEASE MODELS IN WHICH INHIBITION OF RIPK1 IS BENEFICIAL}

The ability of catalytically inactive RIPK1 or small molecule inhibitors of RIPK1 to prevent inflammatory skin disease and multiorgan inflammation in mice lacking Sharpin (Berger et al. 2014), colitis in mice lacking NEMO in intestinal epithelial cells (Vlantis et al. 2016), or inflammation and neurodegeneration in mice heterozygous for both TAK1 and TBK1 in microglia (Xu et al. 2018b) is consistent with the notion that cell death can be a potent driver of inflammatory disease. These genetic disease models reduce or remove known brakes on the activation of RIPK1, but in what other settings might excessive activation of RIPK1 be deleterious and promote disease? Activation of RIPK1 appears to contribute to ischemia-reperfusion injury because mice expressing catalytically inactive RIPK1 show improved survival in a kidney ischemia-reperfusion injury model (Newton et al. 2016a), as do mice dosed with the RIPK1 inhibitor Nec-1 (Linkermann et al. 2012). Nec-1 also reduces reperfusion injury after myocardial infarction in mice and pigs (Oerlemans et al. 2012; Koudstaal et al. 2015). Which cell types activate RIPK1 in these ischemia-reperfusion injury models is unclear. Autophosphorylated RIPK1 is detected in endothelial cells in human heart samples showing acute myocardial infarction (Patel et al. 2019), so the benefits of RIPK1 inhibition may stem from its effects on the vasculature. Mice expressing catalytically inactive RIPK1 also have improved outcomes in an intracerebral hemorrhage stroke model (Lule et al. 2017), plus RIPK1 inhibitors can reduce infarct size in a major cerebral artery occlusion stroke model (Degterev et al. 2005).

Besides ischemia-reperfusion injury, inhibition of RIPK1 pharmacologically or genetically is reported to ameliorate disease in mouse models of retinitis pigmentosa (Murakami et al. 2012), multiple sclerosis (Ofengeim et al. 2015; Zhang et al. 2019b), acetaminophen hepatotoxicity (Dara et al. 2015), atherosclero- sis (Karunakaran et al. 2016), amyotrophic lateral sclerosis (Ito et al. 2016), aortic aneurysm (Wang et al. 2017a), and Alzheimer's disease (Ofengeim et al. 2017). More recent studies have investigated the effect of inhibiting RIPK1 on tumor development, progression, and metastasis, but discrepant results do not produce a clear picture. One group has reported that inhibition of RIPK1 in a mouse model of pancreatic ductal adenocarcinoma slows tumor progression by reprogramming tumor-associated macrophages to promote tumor immunity (Seifert et al. 2016; Wang et al. 2018). An independent study, however, observed no benefit from inhibiting RIPK1 in an intervention setting, and the changes in gene expression that were reported for macrophages expressing catalytically inactive RIPK1 were not replicated (Patel et al. 2019). Contradictory results have also been reported regarding the ability of inhibited RIPK1 to limit tumor cell metastasis (Strilic et al. 2016; Hänggi et al. 2017; Patel et al. 2019), which purportedly acts by either blocking the death of endothelial cells (Strilic et al. 2016) or altering vascular permeability (Hänggi et al. 2017). Unexpectedly, in a mouse model of liver cancer, rather than limiting tumor development, MLKL deficiency or Nec-1 skewed tumor development toward hepatocellular carcinoma instead of intrahepatic cholangiocarcinoma (Seehawer et al. 2018). Necroptosis-associated cytokines were proposed to drive the development of cholangiocarcinoma, but exactly how these cytokines achieve this needs clarification. It is also unclear what triggers hepatocyte necroptosis in this setting.

\section{EFFECT OF INHIBITING RIPK1 ON INNATE IMMUNITY}

Cell death can be an important immune defense against infection, so there are studies that have examined whether inhibition of RIPK1 compromises pathogen clearance. Results have differed depending on the pathogen and the route of infection. Activation of RIPK1 appears beneficial to the host in some infections. For example, mice expressing catalytically inactive RIPK1 are 
K. Newton

less able to clear the Gram-negative bacteria Salmonella typhimurium (Shutinoski et al. 2016) and Yersinia pseudotuberculosis (Peterson et al. 2017). Inhibition of RIPK1 with Nec-1 has also been shown to increase the susceptibility of mice to the fungus Candida albicans (Cao et al. 2019). In other infections, however, activation of RIPK1 appears deleterious to the host. For example, inhibition of RIPK1 with Nec-1s is reported to reduce the number of bacteria in the bronchoalveolar lavage fluid of mice at $4 \mathrm{~h}$ after being dosed intranasally with Gram-positive Staphylococcus aureus (Kitur et al. 2015). In the same study, mice lacking RIPK3 were analyzed at $24 \mathrm{~h}$ after infection, and results were consistent with RIPK1/RIPK3-dependent proinflammatory signals contributing to lung damage and impeding bacterial clearance (Kitur et al. 2015). In contrast, in Staphylococcus aureus skin infection or sepsis models, inhibition of RIPK1 or MLKL deficiency increased bacterial counts and was deleterious (Kitur et al. 2016). Falling into yet a third category, some infections are unaffected by the inhibition of RIPK1. For example, neither Nec-1s nor MLKL deficiency altered bacterial burdens in a humanized mouse model of Mycobacterium tuberculosis infection (Stutz et al. 2018).

In terms of viral infections, mice expressing catalytically inactive RIPK1 are reported to have elevated virus titers in the spleen and liver after intraperitoneal injection of vaccinia virus (Polykratis et al. 2014). It was unclear, however, when after infection the mice were analyzed. Whether the mice eventually cleared the virus or succumbed to infection was not reported. As mentioned earlier, mice expressing catalytically inactive RIPK1 are reported to be more susceptible to infection with West Nile virus or Zika virus (Daniels et al. 2017, 2019). MEFs or mouse macrophages expressing catalytically inactive RIPK1 are killed by influenza A virus just like wild-type cells (Kuriakose et al. 2016; Nogusa et al. 2016), but whether mice clear the virus normally has not been reported. It will be important to explore the role of RIPK1 during infection further as inhibitors of RIPK1 are considered for therapeutic purposes (Harris et al. 2017).

\section{CONCLUDING REMARKS}

Experiments in preclinical disease models highlight the potential therapeutic benefit of inhibiting RIPK1 to limit inflammation and tissue injury, but still there is much we do not understand about this kinase. The kinase-independent prosurvival scaffolding functions of RIPK1, although clear from genetic experiments, are poorly understood at a biochemical level. We would also benefit from further insights into how activation of RIPK1 induces expression of proinflammatory genes independent of cell death. Other areas that merit further examination are the role of RIPK1 in signaling by RIG-I, the role of ubiquitination and proteins such as A20, ABIN1, and XIAP in modulating activation of RIPK1, and the role of RIPK1-dependent signaling in cancer.

\section{ACKNOWLEDGMENTS}

I thank Vishva M. Dixit and Domagoj Vucic for helpful discussions. K.N. is an employee of Genentech.

\section{REFERENCES}

Alvarez-Diaz S, Dillon CP, Lalaoui N, Tanzer MC, Rodriguez DA, Lin A, Lebois M, Hakem R, Josefsson EC O'Reilly LA, et al. 2016. The pseudokinase MLKL and the kinase RIPK3 have distinct roles in autoimmune disease caused by loss of death-receptor-induced apoptosis. Immunity 45: 513-526. doi:10.1016/j.immuni.2016.07 .016

Anderton H, Bandala-Sanchez E, Simpson DS, Rickard JA, Ng AP, Di Rago L, Hall C, Vince JE, Silke J, Liccardi G, et al. 2019. RIPK1 prevents TRADD-driven, but TNFR1 independent, apoptosis during development. Cell Death Differ 26: 877-889. doi:10.1038/s41418-018-0166-8

Annibaldi A, Wicky John S, Vanden Berghe T, Swatek KN, Ruan J, Liccardi G, Bianchi K, Elliot PR, Choi SM, Van Coillie S, et al. 2018. Ubiquitin-mediated regulation of RIPK1 kinase activity independent of IKK and MK2. Mol Cell 69: 566-580.e5. doi:10.1016/j.molcel.2018.01 .027

Bakshi S, Taylor J, Strickson S, McCartney T, Cohen P. 2017 Identification of TBK1 complexes required for the phosphorylation of IRF3 and the production of interferon $\beta$. Biochemical J 474: 1163-1174. doi:10.1042/BCJ20160992

Balachandran S, Thomas E, Barber GN. 2004. A FADD dependent innate immune mechanism in mammalian cells. Nature 432: 401-405. doi:10.1038/nature03124

Berger SB, Kasparcova V, Hoffman S, Swift B, Dare L, Schaeffer M, Capriotti C, Cook M, Finger J, Hughes-Earle 
A, et al. 2014. Cutting edge: RIP1 kinase activity is dispensable for normal development but is a key regulator of inflammation in SHARPIN-deficient mice. J Immunol 192: 5476-5480. doi:10.4049/jimmunol.1400499

Bertrand MJ, Milutinovic S, Dickson KM, Ho WC, Boudreault A, Durkin J, Gillard JW, Jaquith JB, Morris SJ, Barker PA. 2008. cIAP1 and cIAP2 facilitate cancer cell survival by functioning as E3 ligases that promote RIP1 ubiquitination. Mol Cell 30: 689-700. doi:10.1016/j .molcel.2008.05.014

Bonnard M, Mirtsos C, Suzuki S, Graham K, Huang J, Ng M, Itie A, Wakeham A, Shahinian A, Henzel WJ, et al. 2000. Deficiency of T2K leads to apoptotic liver degeneration

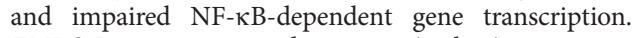
EMBO J 19: 4976-4985. doi:10.1093/emboj/19.18.4976

Bonnet MC, Preukschat D, Welz PS, van Loo G, Ermolaeva MA, Bloch W, Haase I, Pasparakis M. 2011. The adaptor protein FADD protects epidermal keratinocytes from necroptosis in vivo and prevents skin inflammation. Immunity 35: 572-582. doi:10.1016/j.immuni.2011.08.014

Brault M, Olsen TM, Martinez J, Stetson DB, Oberst A. 2018. Intracellular nucleic acid sensing triggers necroptosis through synergistic type I IFN and TNF signaling. J Immunol 200: 2748-2756. doi:10.4049/jimmunol.1701492

Buchrieser J, Oliva-Martin MJ, Moore MD, Long JCD, Cowley SA, Perez-Simón JA, James W, Venero JL. 2018 RIPK1 is a critical modulator of both tonic and TLRresponsive inflammatory and cell death pathways in human macrophage differentiation. Cell Death Dis 9: 973. doi:10.1038/s41419-018-1053-4

Cai Z, Jitkaew S, Zhao J, Chiang HC, Choksi S, Liu J, Ward Y, Wu LG, Liu ZG. 2014. Plasma membrane translocation of trimerized MLKL protein is required for TNF-induced necroptosis. Nat Cell Biol 16: 55-65. doi:10.1038/ncb2883

Callow MG, Watanabe C, Wickliffe KE, Bainer R, Kummerfield S, Weng J, Cuellar T, Janakiraman V, Chen $\mathrm{H}$, Chih $\mathrm{B}$, et al. 2018. CRISPR whole-genome screening identifies new necroptosis regulators and RIPK1 alternative splicing. Cell Death Dis 9: 261. doi:10.1038/s41419-0180301-y

Cao M, Wu Z, Lou Q, Lu W, Zhang J, Li Q, Zhang Y, Yao Y, Zhao Q, Li M, et al. 2019. Dectin-1-induced RIPK1 and RIPK3 activation protects host against Candida albicans infection. Cell Death Differ doi:10.1038/s41418-0190323-8

Ch'en IL, Beisner DR, Degterev A, Yuan J, Hoffmann A, Hedrick SM. 2008. Antigen-mediated T cell expansion regulated by parallel pathways of death. Proc Natl Acad Sci 105: 17463-17468. doi:10.1073/pnas.0808043105

Ch'en IL, Tsau JS, Molkentin JD, Komatsu M, Hedrick SM. 2011. Mechanisms of necroptosis in T cells. J Exp Med 208: 633-641. doi:10.1084/jem.20110251

Chan FK, Shisler J, Bixby JG, Felices M, Zheng L, Appel M, Orenstein J, Moss B, Lenardo MJ. 2003. A role for tumor necrosis factor receptor-2 and receptor-interacting protein in programmed necrosis and antiviral responses. J Biol Chem 278: 51613-51621. doi:10.1074/jbc.M30 5633200

Chang M, Jin W, Sun SC. 2009. Pelil facilitates TRIF-dependent Toll-like receptor signaling and proinflammatory cytokine production. Nat Immunol 10: 1089-1095. doi:10.1038/ni.1777
Chen NJ, Chio II, Lin WJ, Duncan G, Chau H, Katz D, Huang HL, Pike KA, Hao Z, Su YW, et al. 2008. Beyond tumor necrosis factor receptor: TRADD signaling in Tolllike receptors. Proc Natl Acad Sci 105: 12429-12434. doi:10.1073/pnas.0806585105

Chen W, Zhou Z, Li L, Zhong CQ, Zheng X, Wu X, Zhang Y, Ma H, Huang D, Li W, et al. 2013. Diverse sequence determinants control human and mouse receptor interacting protein 3 (RIP3) and mixed lineage kinase domainlike (MLKL) interaction in necroptotic signaling. J Biol Chem 288: 16247-16261. doi:10.1074/jbc.M112.435545

Cheung PC, Nebreda AR, Cohen P. 2004. TAB3, a new binding partner of the protein kinase TAK1. Biochem J 378: 27-34. doi:10.1042/bj20031794

Cho YS, Challa S, Moquin D, Genga R, Ray TD, Guildford M, Chan FK. 2009. Phosphorylation-driven assembly of the RIP1-RIP3 complex regulates programmed necrosis and virus-induced inflammation. Cell 137: 1112-1123. doi:10.1016/j.cell.2009.05.037

Clark K, Peggie M, Plater L, Sorcek RJ, Young ER, Madwed JB, Hough J, McIver EG, Cohen P. 2011. Novel cross-talk within the IKK family controls innate immunity. Biochem J 434: 93-104. doi:10.1042/BJ20101701

Cuchet-Lourenço D, Eletto D, Wu C, Plagnol V, Papapietro O, Curtis J, Ceron-Gutierrez L, Bacon CM, Hackett S, Alsaleem B, et al. 2018. Biallelic RIPK1 mutations in humans cause severe immunodeficiency, arthritis, and intestinal inflammation. Science 361: 810-813. doi:10.1126/ science.aar2641

Cusson-Hermance N, Khurana S, Lee TH, Fitzgerald KA, Kelliher MA. 2005. Rip1 mediates the Trif-dependent Toll-like receptor 3- and 4-induced NF- $\mathrm{\kappa B}$ activation but does not contribute to interferon regulatory factor 3 activation. J Biol Chem 280: 36560-36566. doi:10.1074/ jbc.M506831200

Daniels BP, Snyder AG, Olsen TM, Orozco S, Oguin TH III, Tait SWG, Martinez J, Gale M Jr, Loo YM, Oberst A. 2017. RIPK3 restricts viral pathogenesis via cell deathindependent neuroinflammation. Cell 169: 301-313.e11. doi:10.1016/j.cell.2017.03.011

Daniels BP, Kofman SB, Smith JR, Norris GT, Snyder AG, Kolb JP, Gao X, Locasale JW, Martinez J, Gale M, et al 2019. The nucleotide sensor ZBP1 and kinase RIPK3 induce the enzyme IRG1 to promote an antiviral metabolic state in neurons. Immunity 50: 64-76.e4. doi:10.1016/j .immuni.2018.11.017

Dannappel M, Vlantis K, Kumari S, Polykratis A, Kim C, Wachsmuth L, Eftychi C, Lin J, Corona T, Hermance N, et al. 2014. RIPK1 maintains epithelial homeostasis by inhibiting apoptosis and necroptosis. Nature 513: 90-94. doi:10.1038/nature13608

Dara L, Johnson H, Suda J, Win S, Gaarde W, Han D, Kaplowitz N. 2015. Receptor interacting protein kinase 1 mediates murine acetaminophen toxicity independent of the necrosome and not through necroptosis. Hepatol ogy 62: 1847-1857. doi:10.1002/hep.27939

Degterev A, Huang Z, Boyce M, Li Y, Jagtap P, Mizushima N, Cuny GD, Mitchison TJ, Moskowitz MA, Yuan J. 2005. Chemical inhibitor of nonapoptotic cell death with therapeutic potential for ischemic brain injury. Nat Chem Biol 1: 112-119. doi:10.1038/nchembio711 


\section{K. Newton}

Degterev A, Hitomi J, Germscheid M, Ch'en IL, Korkina O, Teng X, Abbott D, Cuny GD, Yuan C, Wagner G, et al. 2008. Identification of RIP1 kinase as a specific cellular target of necrostatins. Nat Chem Biol 4: 313-321. doi:10 $.1038 /$ nchembio. 83

Dillon CP, Oberst A, Weinlich R, Janke LJ, Kang TB, BenMoshe T, Mak TW, Wallach D, Green DR. 2012. Survival function of the FADD-CASPASE-8-cFLIP $\mathrm{L}_{\mathrm{L}}$ complex. Cell Rep 1: 401-407. doi:10.1016/j.celrep.2012.03.010

Dillon CP, Weinlich R, Rodriguez DA, Cripps JG, Quarato G, Gurung P, Verbist KC, Brewer TL, Llambi F, Gong YN, et al. 2014. RIPK1 blocks early postnatal lethality mediated by caspase- 8 and RIPK3. Cell 157: 1189-1202. doi:10 .1016/j.cell.2014.04.018

Dondelinger Y, Aguileta MA, Goossens V, Dubuisson C, Grootjans S, Dejardin E, Vandenabeele P, Bertrand MJ. 2013. RIPK3 contributes to TNFR1-mediated RIPK1 kinase-dependent apoptosis in conditions of cIAP1/2 depletion or TAK1 kinase inhibition. Cell Death Differ 20: 1381-1392. doi:10.1038/cdd.2013.94

Dondelinger Y, Jouan-Lanhouet S, Divert T, Theatre E, Bertin J, Gough PJ, Giansanti P, Heck AJ, Dejardin E, Van-

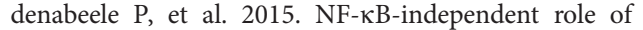
IKK $\alpha / \mathrm{IKK} \beta$ in preventing RIPK1 kinase-dependent apoptotic and necroptotic cell death during TNF signaling. Mol Cell 60: 63-76. doi:10.1016/j.molcel.2015.07.032

Dondelinger Y, Delanghe T, Priem D, Wynosky-Dolfi MA, Dorobetea D, Rojas-Rivera D, Giansanti P, Roelandt R, Gropengiesser J, Ruckdeschel K, et al. 2019. Serine 25 phosphorylation inhibits RIPK1 kinase-dependent cell death in models of infection and inflammation. Nat Commun 10: 1729. doi:10.1038/s41467-019-09690-0

Draber P, Kupka S, Reichert M, Draberova H, Lafont E, de Miguel D, Spilgies L, Surinova S, Taraborrelli L, Hartwig T, et al. 2015. LUBAC-recruited CYLD and A20 regulate gene activation and cell death by exerting opposing effects on linear ubiquitin in signaling complexes. Cell Rep 13: 2258-2272. doi:10.1016/j.celrep.2015.11.009

Dynek JN, Goncharov T, Dueber EC, Fedorova AV, IzraelTomasevic A, Phu L, Helgason E, Fairbrother WJ, Deshayes K, Kirkpatrick DS, et al. 2010. c-IAP1 and UbcH5 promote K11-linked polyubiquitination of RIP1 in TNF signalling. EMBO J 29: 4198-4209. doi:10.1038/emboj .2010 .300

Dziedzic SA, Su Z, Jean Barrett V, Najafov A, Mookhtiar AK, Amin P, Pan H, Sun L, Zhu H, Ma A, et al. 2018. ABIN-1 regulates RIPK1 activation by linking Met1 ubiquitylation with Lys63 deubiquitylation in TNF-RSC. Nat Cell Biol 20: 58-68. doi:10.1038/s41556-017-0003-1

Ea CK, Deng L, Xia ZP, Pineda G, Chen ZJ. 2006. Activation of IKK by TNF $\alpha$ requires site-specific ubiquitination of RIP1 and polyubiquitin binding by NEMO. Mol Cell 22: 245-257. doi:10.1016/j.molcel.2006.03.026

Eliopoulos AG, Wang C, Dumitru CD, Tsichlis PN. 2003. Tpl2 transduces CD40 and TNF signals that activate ERK and regulates IgE induction by CD40. EMBO J 22: 38553864. doi:10.1093/emboj/cdg386

Elliott PR, Leske D, Hrdinka M, Bagola K, Fiil BK, McLaughlin SH, Wagstaff J, Volkmar N, Christianson JC, Kessler BM, et al. 2016. SPATA2 links CYLD to LUBAC, activates CYLD, and controls LUBAC signaling. Mol Cell 63: 9901005. doi:10.1016/j.molcel.2016.08.001
Emmerich CH, Bakshi S, Kelsall IR, Ortiz-Guerrero J, Shpiro N, Cohen P. 2016. Lys63/Met1-hybrid ubiquitin chains are commonly formed during the activation of innate immune signalling. Biochem Biophys Res Commun 474: 452-461. doi:10.1016/j.bbrc.2016.04.141

Enesa K, Ordureau A, Smith H, Barford D, Cheung PC, Patterson-Kane J, Arthur JS, Cohen P. 2012. Pellinol is required for interferon production by viral doublestranded RNA. J Biol Chem 287: 34825-34835. doi:10 $.1074 /$ jbc.M112.367557

Ermolaeva MA, Michallet MC, Papadopoulou N, Utermöhlen O, Kranidioti K, Kollias G, Tschopp J, Pasparakis M. 2008. Function of TRADD in tumor necrosis factor receptor 1 signaling and in TRIF-dependent inflammatory responses. Nat Immunol 9: 1037-1046. doi:10.1038/ni .1638

Fitzgerald KA, McWhirter SM, Faia KL, Rowe DC, Latz E, Golenbock DT, Coyle AJ, Liao SM, Maniatis T. 2003. IKK $\varepsilon$ and TBK1 are essential components of the IRF3 signaling pathway. Nat Immunol 4: 491-496. doi:10 $.1038 /$ ni921

Geng J, Ito Y, Shi L, Amin P, Chu J, Ouchida AT, Mookhtiar AK, Zhao H, Xu D, Shan B, et al. 2017. Regulation of RIPK1 activation by TAK1-mediated phosphorylation dictates apoptosis and necroptosis. Nat Commun 8: 359. doi:10.1038/s41467-017-00406-w

Gerlach B, Cordier SM, Schmukle AC, Emmerich CH, Rieser E, Haas TL, Webb AI, Rickard JA, Anderton H, Wong WW, et al. 2011. Linear ubiquitination prevents inflammation and regulates immune signalling. Nature 471: 591-596. doi:10.1038/nature09816

Guo H, Omoto S, Harris PA, Finger JN, Bertin J, Gough PJ, Kaiser WJ, Mocarski ES. 2015. Herpes simplex virus suppresses necroptosis in human cells. Cell Host Microbe 17: 243-251. doi:10.1016/j.chom.2015.01.003

Guo H, Gilley RP, Fisher A, Lane R, Landsteiner VJ, Ragan KB, Dovey CM, Carette JE, Upton JW, Mocarski ES, et al. 2018. Species-independent contribution of ZBP1/DAI/ DLM-1-triggered necroptosis in host defense against HSV1. Cell Death Dis 9: 816. doi:10.1038/s41419-0180868-3

Haas TL, Emmerich CH, Gerlach B, Schmukle AC, Cordier SM, Rieser E, Feltham R, Vince J, Warnken U, Wenger T, et al. 2009. Recruitment of the linear ubiquitin chain assembly complex stabilizes the TNF-R1 signaling complex and is required for TNF-mediated gene induction. Mol Cell 36: 831-844. doi:10.1016/j.molcel.2009.10.013

Hänggi K, Vasilikos L, Valls AF, Yerbes R, Knop J, Spilgies LM, Rieck K, Misra T, Bertin J, Gough PJ, et al. 2017. RIPK1/RIPK3 promotes vascular permeability to allow tumor cell extravasation independent of its necroptotic function. Cell Death Dis 8: e2588. doi:10.1038/cddis .2017 .20

Harris PA, Berger SB, Jeong JU, Nagilla R, Bandyopadhyay D, Campobasso N, Capriotti CA, Cox JA, Dare L, Dong $\mathrm{X}$, et al. 2017. Discovery of a first-in-class receptor interacting protein 1 (RIP1) kinase specific clinical candidate (GSK2982772) for the treatment of inflammatory diseases. J Med Chem 60: 1247-1261. doi:10.1021/acs .jmedchem.6b01751

He S, Wang L, Miao L, Wang T, Du F, Zhao L, Wang X. 2009. Receptor interacting protein kinase-3 determines cellular 
necrotic response to TNF- $\alpha$. Cell 137: 1100-1111. doi:10 .1016/j.cell.2009.05.021

He S, Liang Y, Shao F, Wang X. 2011. Toll-like receptors activate programmed necrosis in macrophages through a receptor-interacting kinase-3-mediated pathway. Proc Natl Acad Sci 108: 20054-20059. doi:10.1073/pnas .1116302108

Heger K, Wickliffe KE, Ndoja A, Zhang J, Murthy A, Dugger DL, Maltzman A, de Sousa EMF, Hung J, Zeng Y, et al. 2018. OTULIN limits cell death and inflammation by deubiquitinating LUBAC. Nature 559: 120-124. doi:10 .1038/s41586-018-0256-2

Hemmi H, Takeuchi O, Sato S, Yamamoto M, Kaisho T, Sanjo H, Kawai T, Hoshino K, Takeda K, Akira S. 2004. The roles of two IкB kinase-related kinases in lipopolysaccharide and double stranded RNA signaling and viral infection. J Exp Med 199: 1641-1650. doi:10.1084/jem .20040520

Hildebrand JM, Tanzer MC, Lucet IS, Young SN, Spall SK, Sharma P, Pierotti C, Garnier JM, Dobson RC, Webb AI, et al. 2014. Activation of the pseudokinase MLKL unleashes the four-helix bundle domain to induce membrane localization and necroptotic cell death. Proc Natl Acad Sci 111: 15072-15077. doi:10.1073/pnas .1408987111

Hitomi J, Christofferson DE, Ng A, Yao J, Degterev A, Xavier RJ, Yuan J. 2008. Identification of a molecular signaling network that regulates a cellular necrotic cell death pathway. Cell 135: 1311-1323. doi:10.1016/j.cell.2008.10.044

Holler N, Zaru R, Micheau O, Thome M, Attinger A, Valitutti S, Bodmer JL, Schneider P, Seed B, Tschopp J. 2000. Fas triggers an alternative, caspase-8-independent cell death pathway using the kinase RIP as effector molecule. Nat Immunol 1: 489-495. doi:10.1038/82732

Hsu H, Huang J, Shu HB, Baichwal V, Goeddel DV. 1996a. TNF-dependent recruitment of the protein kinase RIP to the TNF receptor-1 signaling complex. Immunity 4: 387396. doi:10.1016/S1074-7613(00)80252-6

Hsu H, Shu HB, Pan MG, Goeddel DV. 1996b. TRADDTRAF2 and TRADD-FADD interactions define two distinct TNF receptor 1 signal transduction pathways. Cell 84: 299-308. doi:10.1016/S0092-8674(00)80984-8

Irmler M, Thome M, Hahne M, Schneider P, Hofmann K, Steiner V, Bodmer JL, Schroter M, Burns K, Mattmann C, et al. 1997. Inhibition of death receptor signals by cellular FLIP. Nature 388: 190-195. doi:10.1038/40657

Ito Y, Ofengeim D, Najafov A, Das S, Saberi S, Li Y, Hitomi J, Zhu H, Chen H, Mayo L, et al. 2016. RIPK1 mediates axonal degeneration by promoting inflammation and necroptosis in ALS. Science 353: 603-608. doi:10.1126/ science.aaf6803

Jaco I, Annibaldi A, Lalaoui N, Wilson R, Tenev T, Laurien L, Kim C, Jamal K, Wicky John S, Liccardi G, et al. 2017. MK2 phosphorylates RIPK1 to prevent TNF-induced cell death. Mol Cell 66: 698-710.e5. doi:10.1016/j.molcel.2017 .05 .003

Jiang Z, Zamanian-Daryoush M, Nie H, Silva AM, Williams BR, Li X. 2003. Poly(I-C)-induced Toll-like receptor 3 (TLR3)-mediated activation of NFKB and MAP kinase is through an interleukin-1 receptor-associated kinase (IRAK)-independent pathway employing the signaling components TLR3-TRAF6-TAK1-TAB2-PKR. J Biol Chem 278: 16713-16719. doi:10.1074/jbc.M300562200

Jiang Z, Mak TW, Sen G, Li X. 2004. Toll-like receptor 3mediated activation of NF- $\mathrm{KB}$ and IRF3 diverges at TollIL-1 receptor domain-containing adapter inducing IFN3. Proc Natl Acad Sci 101: 3533-3538. doi:10.1073/pnas .0308496101

Kaiser WJ, Offermann MK. 2005. Apoptosis induced by the Toll-like receptor adaptor TRIF is dependent on its receptor interacting protein homotypic interaction motif. J Immunol 174: 4942-4952. doi:10.4049/jimmunol.174.8 .4942

Kaiser WJ, Upton JW, Mocarski ES. 2008. Receptor-interacting protein homotypic interaction motif-dependent control of NF- $\kappa \mathrm{B}$ activation via the DNA-dependent activator of IFN regulatory factors. J Immunol 181: 64276434. doi:10.4049/jimmunol.181.9.6427

Kaiser WJ, Upton JW, Long AB, Livingston-Rosanoff D, Daley-Bauer LP, Hakem R, Caspary T, Mocarski ES. 2011. RIP3 mediates the embryonic lethality of caspase8-deficient mice. Nature 471: 368-372. doi:10.1038/na ture09857

Kaiser WJ, Sridharan H, Huang C, Mandal P, Upton JW, Gough PJ, Sehon CA, Marquis RW, Bertin J, Mocarski ES. 2013. Toll-like receptor 3-mediated necrosis via TRIF, RIP3, and MLKL. J Biol Chem 288: 31268-31279. doi:10.1074/jbc.M113.462341

Kaiser WJ, Daley-Bauer LP, Thapa RJ, Mandal P, Berger SB, Huang C, Sundararajan A, Guo H, Roback L, Speck SH, et al. 2014. RIP1 suppresses innate immune necrotic as well as apoptotic cell death during mammalian parturition. Proc Natl Acad Sci 111: 7753-7758. doi:10.1073/pnas .1401857111

Kanayama A, Seth RB, Sun L, Ea CK, Hong M, Shaito A, Chiu YH, Deng L, Chen ZJ. 2004. TAB2 and TAB3 activate the NF- $\mathrm{kB}$ pathway through binding to polyubiquitin chains. Mol Cell 15: 535-548. doi:10.1016/j.molcel .2004 .08 .008

Kang TB, Ben-Moshe T, Varfolomeev EE, Pewzner-Jung Y, Yogev N, Jurewicz A, Waisman A, Brenner O, Haffner R, Gustafsson E, et al. 2004. Caspase-8 serves both apoptotic and nonapoptotic roles. J Immunol 173: 2976-2984. doi:10.4049/jimmunol.173.5.2976

Kang TB, Oh GS, Scandella E, Bolinger B, Ludewig B, Kovalenko A, Wallach D. 2008. Mutation of a self-processing site in caspase- 8 compromises its apoptotic but not its nonapoptotic functions in bacterial artificial chromosome-transgenic mice. J Immunol 181: 2522-2532. doi:10.4049/jimmunol.181.4.2522

Kang TB, Jeong JS, Yang SH, Kovalenko A, Wallach D. 2018. Caspase-8 deficiency in mouse embryos triggers chronic RIPK1-dependent activation of inflammatory genes, independently of RIPK3. Cell Death Differ 25: 1107-1117. doi:10.1038/s41418-018-0104-9

Karunakaran D, Geoffrion M, Wei L, Gan W, Richards L, Shangari P, DeKemp EM, Beanlands RA, Perisic L, Maegdefessel L, et al. 2016. Targeting macrophage necroptosis for therapeutic and diagnostic interventions in atherosclerosis. Sci Adv 2: e1600224. doi:10.1126/sciadv .1600224

Kattah MG, Shao L, Rosli YY, Shimizu H, Whang MI, Advincula R, Achacoso P, Shah S, Duong BH, Onizawa M, et 


\section{K. Newton}

al. 2018. A20 and ABIN-1 synergistically preserve intestinal epithelial cell survival. J Exp Med 215: 1839-1852.

Kelliher MA, Grimm S, Ishida Y, Kuo F, Stanger BZ, Leder P. 1998. The death domain kinase RIP mediates the TNFinduced NF- $\mathrm{KB}$ signal. Immunity 8: 297-303. doi:10 .1016/S1074-7613(00)80535-X

Kitur K, Parker D, Nieto P, Ahn DS, Cohen TS, Chung S, Wachtel S, Bueno S, Prince A. 2015. Toxin-induced necroptosis is a major mechanism of Staphylococcus aureus lung damage. PLoS Pathog 11: e1004820. doi:10.1371/ journal.ppat.1004820

Kitur K, Wachtel S, Brown A, Wickersham M, Paulino F, Peñaloza HF, Soong G, Bueno S, Parker D, Prince A. 2016. Necroptosis promotes Staphylococcus aureus clearance by inhibiting excessive inflammatory signaling. Cell Rep 16: 2219-2230. doi:10.1016/j.celrep.2016.07.039

Kondylis V, Polykratis A, Ehlken H, Ochoa-Callejero L, Straub BK, Krishna-Subramanian S, Van TM, Curth HM, Heise N, Weih F, et al. 2015. NEMO prevents steatohepatitis and hepatocellular carcinoma by inhibiting RIPK1 kinase activity-mediated hepatocyte apoptosis. Cancer Cell 28: 582-598. doi:10.1016/j.ccell.2015.10.001

Koudstaal S, Oerlemans MI, Van der Spoel TI, Janssen AW, Hoefer IE, Doevendans PA, Sluijter JP, Chamuleau SA. 2015. Necrostatin-1 alleviates reperfusion injury following acute myocardial infarction in pigs. Eur J Clin Invest 45: 150-159. doi:10.1111/eci.12391

Kreuz S, Siegmund D, Scheurich P, Wajant H. 2001. NF-кB inducers upregulate cFLIP, a cycloheximide-sensitive inhibitor of death receptor signaling. Mol Cell Biol 21: 3964-3973. doi:10.1128/MCB.21.12.3964-3973.2001

Krikos A, Laherty CD, Dixit VM. 1992. Transcriptional activation of the tumor necrosis factor $\alpha$-inducible zinc finger protein, $\mathrm{A} 20$, is mediated by $\mathrm{\kappa B}$ elements. $J$ Biol Chem 267: 17971-17976.

Kumari S, Redouane Y, Lopez-Mosqueda J, Shiraishi R, Romanowska M, Lutzmayer S, Kuiper J, Martinez C, Dikic I, Pasparakis M, et al. 2014. Sharpin prevents skin inflammation by inhibiting TNFR1-induced keratinocyte apoptosis. eLife 3: e03422. doi:10.7554/eLife.03422

Kupka S, De Miguel D, Draber P, Martino L, Surinova S, Rittinger K, Walczak H. 2016. SPATA2-mediated binding of CYLD to HOIP enables CYLD recruitment to signaling complexes. Cell Rep 16: 2271-2280. doi:10.1016/j.celrep .2016 .07 .086

Kuriakose T, Man SM, Malireddi RK, Karki R, Kesavardhana S, Place DE, Neale G, Vogel P, Kanneganti TD. 2016 $\mathrm{ZBP} 1 / \mathrm{DAI}$ is an innate sensor of influenza virus triggering the NLRP3 inflammasome and programmed cell death pathways. Sci Immunol 1: aag2045. doi:10.1126/ sciimmunol.aag2045

Lafont E, Draber P, Rieser E, Reichert M, Kupka S, de Miguel D, Draberova H, von Massenhausen A, Bhamra A, Henderson S, et al. 2018. TBK1 and IKKe prevent TNF-induced cell death by RIPK1 phosphorylation. Nat Cell Biol 20: 1389-1399. doi:10.1038/s41556-018-0229-6

Lamothe B, Lai Y, Xie M, Schneider MD, Darnay BG. 2013. TAK1 is essential for osteoclast differentiation and is an important modulator of cell death by apoptosis and necroptosis. Mol Cell Biol 33: 582-595. doi:10.1128/MCB $.01225-12$
Lee TH, Shank J, Cusson N, Kelliher MA. 2004. The kinase activity of Rip1 is not required for tumor necrosis factor$\alpha$-induced IкB kinase or p38 MAP kinase activation or for the ubiquitination of Rip1 by Traf2. J Biol Chem 279: 33185-33191. doi:10.1074/jbc.M404206200

Legarda D, Justus SJ, Ang RL, Rikhi N, Li W, Moran TM, Zhang J, Mizoguchi E, Zelic M, Kelliher MA, et al. 2016. CYLD proteolysis protects macrophages from TNF-mediated auto-necroptosis induced by LPS and licensed by type I IFN. Cell Rep 15: 2449-2461. doi:10.1016/j.celrep 2016.05.032

Li Y, Fuhrer M, Bahrami E, Socha P, Dlaudel-Dreszler M, Bouzidi A, Liu Y, Lehle AS, Magg T, Hollizeck S, et al. 2019. Human RIPK1 deficiency causes combined immunodeficiency and inflammatory bowel diseases. Proc Natl Acad Sci 116: 970-975. doi:10.1073/pnas.1813582116

Lin Y, Devin A, Rodriguez Y, Liu ZG. 1999. Cleavage of the death domain kinase RIP by caspase- 8 prompts TNFinduced apoptosis. Genes Dev 13: 2514-2526. doi:10 $.1101 /$ gad.13.19.2514

Lin J, Kumari S, Kim C, Van TM, Wachsmuth L, Polykratis A, Pasparakis M. 2016. RIPK1 counteracts ZBP1-mediated necroptosis to inhibit inflammation. Nature 540: 124128. doi: $10.1038 /$ nature20558

Linkermann A, Bräsen JH, Himmerkus N, Liu S, Huber TB, Kunzendorf U, Krautwald S. 2012. Rip1 (receptor-interacting protein kinase 1) mediates necroptosis and contributes to renal ischemia/reperfusion injury. Kidney Int 81: 751-761. doi:10.1038/ki.2011.450

Liu S, Chen J, Cai X, Wu J, Chen X, Wu YT, Sun L, Chen ZJ. 2013. MAVS recruits multiple ubiquitin E3 ligases to activate antiviral signaling cascades. eLife 2: e00785. doi:10 $.7554 /$ eLife. 00785

Liu S, Cai X, Wu J, Cong Q, Chen X, Li T, Du F, Ren J, Wu YT, Grishin NV, et al. 2015. Phosphorylation of innate immune adaptor proteins MAVS, STING, and TRIF induces IRF3 activation. Science 347: aaa2630. doi:10.1126/ science.aaa2630

Lo YC, Lin SC, Rospigliosi CC, Conze DB, Wu CJ, Ashwell JD, Eliezer D, Wu H. 2009. Structural basis for recognition of diubiquitins by NEMO. Mol Cell 33: 602-615. doi:10.1016/j.molcel.2009.01.012

Lule S, Wu L, McAllister LM, Edmiston WJ, Chung JY, Levy E, Zheng Y, Gough PJ, Bertin J, Degterev A, et al. 2017. Genetic inhibition of receptor interacting protein kinase1 reduces cell death and improves functional outcome after intracerebral hemorrhage in mice. Stroke 48: 2549-2556. doi:10.1161/STROKEAHA.117.017702

Maelfait J, Liverpool L, Bridgeman A, Ragan KB, Upton JW, Rehwinkel J. 2017. Sensing of viral and endogenous RNA by ZBP1/DAI induces necroptosis. EMBO J 36: 25292543. doi:10.15252/embj.201796476

Mahoney DJ, Cheung HH, Mrad RL, Plenchette S, Simard C, Enwere E, Arora V, Mak TW, Lacasse EC, Waring J, et al. 2008. Both cIAP1 and cIAP2 regulate TNFo-mediated

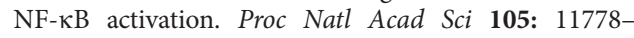
11783. doi:10.1073/pnas.0711122105

Matsui K, Kumagai Y, Kato H, Sato S, Kawagoe T, Uematsu S, Takeuchi O, Akira S. 2006. Cutting edge: Role of TANK-binding kinase 1 and inducible IкB kinase in IFN responses against viruses in innate immune cells. $J$ 
Immunol 177: 5785-5789. doi:10.4049/jimmunol.177.9 .5785

McComb S, Cessford E, Alturki NA, Joseph J, Shutinoski B, Startek JB, Gamero AM, Mossman KL, Sad S. 2014. TypeI interferon signaling through ISGF3 complex is required for sustained Rip3 activation and necroptosis in macrophages. Proc Natl Acad Sci 111: E3206-E3213. doi:10 $.1073 /$ pnas. 1407068111

McWhirter SM, Fitzgerald KA, Rosains J, Rowe DC, Golenbock DT, Maniatis T. 2004. IFN-regulatory factor 3-dependent gene expression is defective in Tbk1-deficient mouse embryonic fibroblasts. Proc Natl Acad Sci 101: 233-238. doi:10.1073/pnas.2237236100

Meng H, Liu Z, Li X, Wang H, Jin T, Wu G, Shan B, Christofferson DE, Qi C, Yu Q, et al. 2018. Death-domain dimerization-mediated activation of RIPK1 controls necroptosis and RIPK1-dependent apoptosis. Proc Natl Acad Sci 115: E2001-E2009. doi:10.1073/pnas.1722013115

Menon MB, Gropengießer J, Fischer J, Novikova L, Deuretzbacher A, Lafera J, Schimmeck $\mathrm{H}$, Czymmeck N, Ronkina N, Kotlyarov A, et al. 2017. p38 $8^{\mathrm{MAPK}} / \mathrm{MK} 2$-dependent phosphorylation controls cytotoxic RIPK1 signalling in inflammation and infection. Nat Cell Biol 19: 1248-1259. doi:10.1038/ncb3614

Meylan E, Burns K, Hofmann K, Blancheteau V, Martinon F, Kelliher M, Tschopp J. 2004. RIP1 is an essential mediator of Toll-like receptor 3-induced NF- $\mathrm{\kappa B}$ activation. Nat Immunol 5: 503-507. doi:10.1038/ni1061

Michallet MC, Meylan E, Ermolaeva MA, Vazquez J, Rebsamen M, Curran J, Poeck H, Bscheider M, Hartmann G, Konig M, et al. 2008. TRADD protein is an essential component of the RIG-like helicase antiviral pathway. Immunity 28: 651-661. doi:10.1016/j.immuni.2008.03 .013

Micheau O, Tschopp J. 2003. Induction of TNF receptor I-mediated apoptosis via two sequential signaling complexes. Cell 114: 181-190. doi:10.1016/S0092-8674(03) 00521-X

Mompeán M, Li W, Li J, Laage S, Siemer AB, Bozkurt G, Wu $\mathrm{H}, \mathrm{McDermott}$ AE. 2018. The structure of the necrosome RIPK1-RIPK3 Core, a human hetero-amyloid signaling complex. Cell 173: 1244-1253.e10. doi:10.1016/j.cell .2018 .03 .032

Moquin DM, McQuade T, Chan FK. 2013. CYLD deubiquitinates RIP1 in the TNF $\alpha$-induced necrosome to facilitate kinase activation and programmed necrosis. PLoS ONE 8: e76841. doi:10.1371/journal.pone.0076841

Moulin M, Anderton H, Voss AK, Thomas T, Wong WW, Bankovacki A, Feltham R, Chau D, Cook WD, Silke J, et al. 2012. IAPs limit activation of RIP kinases by TNF receptor 1 during development. EMBO J 31: 1679-1691. doi:10.1038/emboj.2012.18

Murakami Y, Matsumoto H, Roh M, Suzuki J, Hisatomi T, Ikeda Y, Miller JW, Vavvas DG. 2012. Receptor interacting protein kinase mediates necrotic cone but not rod cell death in a mouse model of inherited degeneration. Proc Natl Acad Sci 109: 14598-14603. doi:10.1073/pnas .1206937109

Murphy JM, Czabotar PE, Hildebrand JM, Lucet IS, Zhang JG, Alvarez-Diaz S, Lewis R, Lalaoui N, Metcalf D, Webb AI, et al. 2013. The pseudokinase MLKL mediates nec- roptosis via a molecular switch mechanism. Immunity 39: 443-453. doi:10.1016/j.immuni.2013.06.018

Najjar M, Saleh D, Zelic M, Nogusa S, Shah S, Tai A, Finger JN, Polykratis A, Gough PJ, Bertin J, et al. 2016. RIPK1 and RIPK3 kinases promote cell-death-independent inflammation by Toll-like receptor 4. Immunity 45: 46-59. doi:10.1016/j.immuni.2016.06.007

Newton K, Dugger DL, Wickliffe KE, Kapoor N, de Almagro MC, Vucic D, Komuves L, Ferrando RE, French DM, Webster J, et al. 2014. Activity of protein kinase RIPK3 determines whether cells die by necroptosis or apoptosis Science 343: 1357-1360. doi:10.1126/science.1249361

Newton K, Dugger DL, Maltzman A, Greve JM, Hedehus M, Martin-McNulty B, Carano RA, Cao TC, van Bruggen N, Bernstein L, et al. 2016a. RIPK3 deficiency or catalytically inactive RIPK1 provides greater benefit than MLKL deficiency in mouse models of inflammation and tissue injury. Cell Death Differ 23: 1565-1576. doi:10.1038/cdd.2016 46

Newton K, Wickliffe KE, Maltzman A, Dugger DL, Strasser A, Pham VC, Lill JR, Roose-Girma M, Warming S, Solon $\mathrm{M}$, et al. 2016b. RIPK1 inhibits ZBP1-driven necroptosis during development. Nature 540: 129-133. doi:10.1038/ nature20559

Nogusa S, Thapa RJ, Dillon CP, Liedmann S, Oguin TH III, Ingram JP, Rodriguez DA, Kosoff R, Sharma S, Sturm O, et al. 2016. RIPK3 activates parallel pathways of MLKLdriven necroptosis and FADD-mediated apoptosis to protect against influenza A virus. Cell Host Microbe 20: 13-24. doi:10.1016/j.chom.2016.05.011

Oberst A, Dillon CP, Weinlich R, McCormick LL, Fitzgerald P, Pop C, Hakem R, Salvesen GS, Green DR. 2011. Catalytic activity of the caspase-8-FLIP $\mathrm{L}_{\mathrm{L}}$ complex inhibits RIPK3-dependent necrosis. Nature 471: 363-367. doi:10.1038/nature09852

O’Donnell MA, Perez-Jimenez E, Oberst A, Ng A, Massoumi R, Xavier R, Green DR, Ting AT. 2011. Caspase 8 inhibits programmed necrosis by processing CYLD. Nat Cell Biol 13: 1437-1442. doi:10.1038/ncb2362

Oerlemans MI, Liu J, Arslan F, den Ouden K, van Middelaar BJ, Doevendans PA, Sluijter JP. 2012. Inhibition of RIP1dependent necrosis prevents adverse cardiac remodeling after myocardial ischemia-reperfusion in vivo. Basic Res Cardiol 107: 270. doi:10.1007/s00395-012-0270-8

Ofengeim D, Ito Y, Najafov A, Zhang Y, Shan B, DeWitt JP, Ye J, Zhang X, Chang A, Vakifahmetoglu-Norberg H, et al. 2015. Activation of necroptosis in multiple sclerosis. Cell Rep 10: 1836-1849. doi:10.1016/j.celrep.2015.02.051

Ofengeim D, Mazzitelli S, Ito Y, DeWitt JP, Mifflin L, Zou C, Das S, Adiconis X, Chen H, Zhu H, et al. 2017. RIPK1 mediates a disease-associated microglial response in Alzheimer's disease. Proc Natl Acad Sci 114: E8788-E8797. doi:10.1073/pnas.1714175114

Onizawa M, Oshima S, Schulze-Topphoff U, Oses-Prieto JA, Lu T, Tavares R, Prodhomme T, Duong B, Whang MI Advincula R, et al. 2015. The ubiquitin-modifying enzyme A20 restricts ubiquitination of the kinase RIPK3 and protects cells from necroptosis. Nat Immunol 16: 618-627. doi:10.1038/ni.3172

Orning P, Weng D, Starheim K, Ratner D, Best Z, Lee B, Brooks A, Xia S, Wu H, Kelliher MA, et al. 2018. Pathogen blockade of TAK1 triggers caspase-8-dependent cleavage 


\section{K. Newton}

of gasdermin D and cell death. Science 362: 1064-1069. doi:10.1126/science.aau2818

Orozco S, Yatim N, Werner MR, Tran H, Gunja SY, Tait SW, Albert ML, Green DR, Oberst A. 2014. RIPK1 both positively and negatively regulates RIPK3 oligomerization and necroptosis. Cell Death Differ 21: 1511-1521. doi:10.1038/cdd.2014.76

Oshima S, Turer EE, Callahan JA, Chai S, Advincula R, Barrera J, Shifrin N, Lee B, Benedict Yen TS, Woo T, et al. 2009. ABIN-1 is a ubiquitin sensor that restricts cell death and sustains embryonic development. Nature 457: 906-909. doi:10.1038/nature07575

Park YH, Jeong MS, Park HH, Jang SB. 2013. Formation of the death domain complex between FADD and RIP1 proteins in vitro. Biochim Biophys Acta 1834: 292-300. doi:10.1016/j.bbapap.2012.08.013

Patel S, Webster JD, Varfolomeev E, Kwon YC, Cheng JH, Zhang J, Dugger DL, Wickliffe KE, Maltzman A, SujathaBhaskar S, et al. 2019. RIP1 inhibition blocks inflammatory diseases but not tumor growth or metastases. Cell Death Differ doi: 10.1038/s41418-019-0347-0.

Pattison MJ, Mitchell O, Flynn HR, Chen CS, Yang HT, BenAddi H, Boeing S, Snijders AP, Ley SC. 2016. TLR and TNF-R1 activation of the MKK3/MKK6-p38 $\alpha$ axis in macrophages is mediated by TPL-2 kinase. Biochem $J$ 473: 2845-2861. doi:10.1042/BCJ20160502

Peltzer N, Rieser E, Taraborrelli L, Draber P, Darding M, Pernaute B, Shimizu Y, Sarr A, Draberova H, Montinaro A, et al. 2014. HOIP deficiency causes embryonic lethality by aberrant TNFR1-mediated endothelial cell death. Cell Rep 9: 153-165. doi:10.1016/j.celrep.2014.08.066

Peltzer N, Darding M, Montinaro A, Draber P, Draberova H, Kupka S, Rieser E, Fisher A, Hutchinson C, Taraborrelli L, et al. 2018. LUBAC is essential for embryogenesis by preventing cell death and enabling haematopoiesis. Nature 557: 112-117. doi:10.1038/s41586-018-0064-8

Perry AK, Chow EK, Goodnough JB, Yeh WC, Cheng G. 2004. Differential requirement for TANK-binding kinase-1 in type I interferon responses to Toll-like receptor activation and viral infection. J Exp Med 199: 1651-1658. doi:10.1084/jem.20040528

Peterson LW, Philip NH, DeLaney A, Wynosky-Dolfi MA, Asklof K, Gray F, Choa R, Bjanes E, Buza EL, Hu B, et al. 2017. RIPK1-dependent apoptosis bypasses pathogen blockade of innate signaling to promote immune defense. J Exp Med 214: 3171-3182. doi:10.1084/jem.20170347

Petrie EJ, Sandow JJ, Jacobsen AV, Smith BJ, Griffin MDW Lucet IS, Dai W, Young SN, Tanzer MC, Wardak A, et al 2018. Conformational switching of the pseudokinase domain promotes human MLKL tetramerization and cell death by necroptosis. Nat Commun 9: 2422. doi:10 .1038/s41467-018-04714-7

Pobezinskaya YL, Kim YS, Choksi S, Morgan MJ, Li T, Liu C Liu Z. 2008. The function of TRADD in signaling through tumor necrosis factor receptor 1 and TRIF-dependent Toll-like receptors. Nat Immunol 9: 1047-1054. doi:10 $.1038 /$ ni.1639

Polykratis A, Hermance N, Zelic M, Roderick J, Kim C, Van TM, Lee TH, Chan FK, Pasparakis M, Kelliher MA. 2014 Cutting edge: RIPK1 Kinase inactive mice are viable and protected from TNF-induced necroptosis in vivo. $\mathrm{J} \mathrm{Im}$ munol 193: 1539-1543. doi:10.4049/jimmunol.1400590
Polykratis A, Martens A, Eren RO, Shirasaki Y, Yamagishi M, Yamaguchi Y, Uemura S, Miura M, Holzmann B, Kollias $\mathrm{G}$, et al. 2019. A20 prevents inflammasome-dependent arthritis by inhibiting macrophage necroptosis through its ZnF7 ubiquitin-binding domain. Nat Cell Biol 21: 731-742. doi:10.1038/s41556-019-0324-3

Rahighi S, Ikeda F, Kawasaki M, Akutsu M, Suzuki N, Kato R, Kensche T, Uejima T, Bloor S, Komander D, et al. 2009. Specific recognition of linear ubiquitin chains by NEMO is important for NF- $\mathrm{\kappa B}$ activation. Cell 136: 1098-1109. doi:10.1016/j.cell.2009.03.007

Rajput A, Kovalenko A, Bogdanov K, Yang SH, Kang TB, Kim JC, Du J, Wallach D. 2011. RIG-I RNA helicase activation of IRF3 transcription factor is negatively regulated by caspase-8-mediated cleavage of the RIP1 protein. Immunity 34: 340-351. doi:10.1016/j.immuni.2010.12 .018

Raju S, Whalen DM, Mengistu M, Swanson C, Quinn JG, Taylor SS, Webster JD, Newton K, Shaw AS. 2018. Kinase domain dimerization drives RIPK3-dependent necroptosis. Sci Signal 11: eaar2188. doi: 10.1126/scisig nal.aar2188

Rickard JA, Anderton H, Etemadi N, Nachbur U, Darding M, Peltzer N, Lalaoui N, Lawlor KE, Vanyai H, Hall C, et al. 2014a. TNFR1-dependent cell death drives inflammation in Sharpin-deficient mice. eLife 3: e03464. doi:10 .7554/eLife.03464

Rickard JA, O'Donnell JA, Evans JM, Lalaoui N, Poh AR, Rogers T, Vince JE, Lawlor KE, Ninnis RL, Anderton H, et al. 2014b. RIPK1 regulates RIPK3-MLKL-driven systemic inflammation and emergency hematopoiesis. Cell 157: 1175-1188. doi:10.1016/j.cell.2014.04.019

Rijal D, Ariana A, Wight A, Kim K, Alturki NA, Aamir Z, Ametepe ES, Korneluk RG, Tiedje C, Menon MB, et al. 2018. Differentiated macrophages acquire a pro-inflammatory and cell death-resistant phenotype due to increasing XIAP and p38-mediated inhibition of RipK1. J Biol Chem 293: 11913-11927. doi:10.1074/jbc.RA118 .003614

Roderick JE, Hermance N, Zelic M, Simmons MJ, Polykratis A, Pasparakis M, Kelliher MA. 2014. Hematopoietic RIPK1 deficiency results in bone marrow failure caused by apoptosis and RIPK3-mediated necroptosis. Proc Natl Acad Sci 111: 14436-14441. doi:10.1073/pnas .1409389111

Rodriguez DA, Weinlich R, Brown S, Guy C, Fitzgerald P, Dillon CP, Oberst A, Quarato G, Low J, Cripps JG, et al. 2016. Characterization of RIPK3-mediated phosphorylation of the activation loop of MLKL during necroptosis. Cell Death Differ 23: 76-88. doi:10.1038/cdd .2015 .70

Saleh D, Najjar M, Zelic M, Shah S, Nogusa S, Polykratis A, Paczosa MK, Gough PJ, Bertin J, Whalen M, et al. 2017. Kinase activities of RIPK1 and RIPK 3 can direct IFN- $\beta$ synthesis induced by lipopolysaccharide. J Immunol 198: 4435-4447. doi:10.4049/jimmunol.1601717

Sato S, Sugiyama M, Yamamoto M, Watanabe Y, Kawai T, Takeda K, Akira S. 2003. Toll/IL-1 receptor domain-containing adaptor inducing IFN- $\beta$ (TRIF) associates with TNF receptor-associated factor 6 and TANK-binding kinase 1 , and activates two distinct transcription factors, NF- $\kappa \mathrm{B}$ and IFN-regulatory factor-3, in the Toll-like re- 
ceptor signaling. J Immunol 171: 4304-4310. doi:10 .4049/jimmunol.171.8.4304

Schlicher L, Wissler M, Preiss F, Brauns-Schubert P, Jakob C, Dumit V, Borner C, Dengjel J, Maurer U. 2016. SPATA2 promotes CYLD activity and regulates TNF-induced NFКB signaling and cell death. EMBO Rep 17: 1485-1497. doi:10.15252/embr.201642592

Schock SN, Chandra NV, Sun Y, Irie T, Kitagawa Y, Gotoh B, Coscoy L, Winoto A. 2017. Induction of necroptotic cell death by viral activation of the RIG-I or STING pathway. Cell Death Differ 24: 615-625. doi:10.1038/cdd.2016 .153

Seehawer M, Heinzmann F, D’Artista L, Harbig J, Roux PF, Hoenicke L, Dang H, Klotz S, Robinson L, Doré G, et al. 2018. Necroptosis microenvironment directs lineage commitment in liver cancer. Nature 562: 69-75. doi:10 $.1038 / \mathrm{s} 41586-018-0519-\mathrm{y}$

Seifert L, Werba G, Tiwari S, Giao Ly NN, Alothman S, Alqunaibit D, Avanzi A, Barilla R, Daley D, Greco $\mathrm{SH}$, et al. 2016. The necrosome promotes pancreatic oncogenesis via CXCL1 and Mincle-induced immune suppression. Nature 532: 245-249. doi:10.1038/na ture 17403

Shim JH, Xiao C, Paschal AE, Bailey ST, Rao P, Hayden MS, Lee KY, Bussey C, Steckel M, Tanaka N, et al. 2005. TAK1, but not TAB1 or TAB2, plays an essential role in multiple signaling pathways in vivo. Genes Dev 19: 2668-2681. doi:10.1101/gad.1360605

Shu HB, Takeuchi M, Goeddel DV. 1996. The tumor necrosis factor receptor 2 signal transducers TRAF2 and cIAP1 are components of the tumor necrosis factor receptor 1 signaling complex. Proc Natl Acad Sci 93: 1397313978. doi:10.1073/pnas.93.24.13973

Shutinoski B, Alturki NA, Rijal D, Bertin J, Gough PJ, Schlossmacher MG, Sad S. 2016. K45A mutation of RIPK1 results in poor necroptosis and cytokine signaling in macrophages, which impacts inflammatory responses in vivo. Cell Death Differ 23: 1628-1637. doi:10.1038/cdd .2016 .51

Stanger BZ, Leder P, Lee TH, Kim E, Seed B. 1995. RIP: A novel protein containing a death domain that interacts with Fas/APO-1 (CD95) in yeast and causes cell death. Cell 81: 513-523. doi:10.1016/0092-8674(95)90072-1

Stehlik C, de Martin R, Kumabashiri I, Schmid JA, Binder

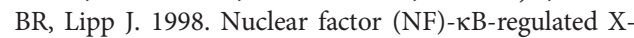
chromosome-linked iap gene expression protects endothelial cells from tumor necrosis factor $\alpha$-induced apoptosis. J Exp Med 188: 211-216. doi:10.1084/jem.188.1 .211

Strilic B, Yang L, Albarrán-Juárez J, Wachsmuth L, Han K, Müller UC, Pasparakis M, Offermanns S. 2016. Tumourcell-induced endothelial cell necroptosis via death receptor 6 promotes metastasis. Nature 536: 215-218. doi:10 $.1038 /$ nature 19076

Stutz MD, Ojaimi S, Allison C, Preston S, Arandjelovic P, Hildebrand JM, Sandow JJ, Webb AI, Silke J, Alexander WS, et al. 2018. Necroptotic signaling is primed in $M y$ cobacterium tuberculosis-infected macrophages, but its pathophysiological consequence in disease is restricted. Cell Death Differ 25: 951-965. doi:10.1038/s41418-0170031-1
Su L, Quade B, Wang H, Sun L, Wang X, Rizo J. 2014. A plug release mechanism for membrane permeation by MLKL. Structure 22: 1489-1500. doi:10.1016/j.str.2014.07.014

Sun X, Yin J, Starovasnik MA, Fairbrother WJ, Dixit VM. 2002. Identification of a novel homotypic interaction motif required for the phosphorylation of receptor-interacting protein (RIP) by RIP3. J Biol Chem 277: 9505-9511. doi:10.1074/jbc.M109488200

Sun L, Wang H, Wang Z, He S, Chen S, Liao D, Wang L, Yan J, Liu W, Lei X, et al. 2012. Mixed lineage kinase domainlike protein mediates necrosis signaling downstream of RIP3 kinase. Cell 148: 213-227. doi:10.1016/j.cell.2011 .11 .031

Takahashi N, Vereecke L, Bertrand MJ, Duprez L, Berger SB, Divert T, Gonçalves A, Sze M, Gilbert B, Kourula S, et al. 2014. RIPK1 ensures intestinal homeostasis by protecting the epithelium against apoptosis. Nature 513: 95-99. doi:10.1038/nature13706

Thapa RJ, Ingram JP, Ragan KB, Nogusa S, Boyd DF, Benitez AA, Sridharan H, Kosoff R, Shubina M, Landsteiner VJ, et al. 2016. DAI senses influenza A virus genomic RNA and activates RIPK3-dependent cell death. Cell Host Microbe 20: 674-681. doi:10.1016/j.chom.2016.09.014

Ting AT, Pimentel-Muiños FX, Seed B. 1996. RIP mediates tumor necrosis factor receptor 1 activation of NF- $\mathrm{\kappa B}$ but not Fas/APO-1-initiated apoptosis. EMBO J 15: 61896196. doi:10.1002/j.1460-2075.1996.tb01007.x

Tokunaga F, Nakagawa T, Nakahara M, Saeki Y, Taniguchi M, Sakata S, Tanaka K, Nakano H, Iwai K. 2011. SHAR$\mathrm{PIN}$ is a component of the NF- $\mathrm{KB}$-activating linear ubiquitin chain assembly complex. Nature 471: 633-636. doi:10.1038/nature09815

Tournier C, Dong C, Turner TK, Jones SN, Flavell RA, Davis RJ. 2001. MKK7 is an essential component of the JNK signal transduction pathway activated by proinflammatory cytokines. Genes Dev 15: 1419-1426. doi:10.1101/ gad. 888501

Upton JW, Kaiser WJ, Mocarski ES. 2012. DAI/ZBP1/DLM1 complexes with RIP3 to mediate virus-induced programmed necrosis that is targeted by murine cytomegalovirus vIRA. Cell Host Microbe 11: 290-297. doi:10.1016/ j.chom.2012.01.016

Van TM, Polykratis A, Straub BK, Kondylis V, Papadopoulou N, Pasparakis M. 2017. Kinase-independent functions of RIPK1 regulate hepatocyte survival and liver carcinogenesis. J Clin Invest 127: 2662-2677. doi:10.1172/JCI 92508

Vanlangenakker N, Vanden Berghe T, Bogaert P, Laukens B, Zobel K, Deshayes K, Vucic D, Fulda S, Vandenabeele P, Bertrand MJ. 2011. cIAP1 and TAK1 protect cells from TNF-induced necrosis by preventing RIP1/RIP3-dependent reactive oxygen species production. Cell Death Differ 18: 656-665. doi:10.1038/cdd.2010.138

Varfolomeev EE, Schuchmann M, Luria V, Chiannilkulchai N, Beckmann JS, Mett IL, Rebrikov D, Brodianski VM Kemper OC, Kollet O, et al. 1998. Targeted disruption of the mouse Caspase 8 gene ablates cell death induction by the TNF receptors, Fas/Apo1, and DR3 and is lethal prenatally. Immunity 9: 267-276. doi:10.1016/S1074-7613 (00)80609-3

Varfolomeev E, Goncharov T, Fedorova AV, Dynek JN, Zobel K, Deshayes K, Fairbrother WJ, Vucic D. 2008. c-IAP1 


\section{K. Newton}

and c-IAP2 are critical mediators of tumor necrosis factor $\alpha$ (TNF $\alpha$ )-induced NF- $\kappa B$ activation. J Biol Chem 283: 24295-24299. doi:10.1074/jbc.C800128200

Vince JE, Pantaki D, Feltham R, Mace PD, Cordier SM, Schmukle AC, Davidson AJ, Callus BA, Wong WW, Gentle IE, et al. 2009. TRAF2 must bind to cellular inhibitors of apoptosis for tumor necrosis factor (TNF) to efficiently activate NF- $\mathrm{KB}$ and to prevent TNF-induced apoptosis. J Biol Chem 284: 35906-35915. doi:10.1074/jbc.M109 .072256

Vlantis K, Wullaert A, Polykratis A, Kondylis V, Dannappel M, Schwarzer R, Welz P, Corona T, Walczak H, Weih F, et al. 2016. NEMO prevents RIP kinase 1-mediated epithelial cell death and chronic intestinal inflammation by NF- $\kappa \mathrm{B}$-dependent and -independent functions. Immunity 44: 553-567. doi:10.1016/j.immuni.2016.02 .020

Wagner SA, Satpathy S, Beli P, Choudhary C. 2016. SPATA2 links CYLD to the TNF- $\alpha$ receptor signaling complex and modulates the receptor signaling outcomes. EMBO J 35: 1868-1884. doi:10.15252/embj.201694300

Wang CY, Mayo MW, Korneluk RG, Goeddel DV, Baldwin

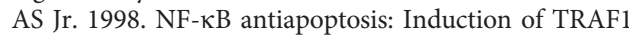
and TRAF2 and c-IAP1 and c-IAP2 to suppress caspase- 8 activation. Science 281: 1680-1683. doi:10.1126/science .281.5383.1680

Wang L, Du F, Wang X. 2008. TNF- $\alpha$ induces two distinct caspase-8 activation pathways. Cell 133: 693-703. doi:10 $.1016 /$ j.cell.2008.03.036

Wang H, Sun L, Su L, Rizo J, Liu L, Wang LF, Wang FS, Wang X. 2014. Mixed lineage kinase domain-like protein MLKL causes necrotic membrane disruption upon phosphorylation by RIP3. Mol Cell 54: 133-146. doi:10.1016/j .molcel.2014.03.003

Wang Q, Zhou T, Liu Z, Ren J, Phan N, Gupta K, Stewart DM, Morgan S, Assa C, Kent KC, et al. 2017a. Inhibition of receptor-interacting protein kinase 1 with necrostatin$1 \mathrm{~s}$ ameliorates disease progression in elastase-induced mouse abdominal aortic aneurysm model. Sci Rep 7: 42159. doi:10.1038/srep42159

Wang Y, Gao W, Shi X, Ding J, Liu W, He H, Wang K, Shao F. 2017b. Chemotherapy drugs induce pyroptosis through caspase-3 cleavage of a gasdermin. Nature 547: 99-103. doi:10.1038/nature22393

Wang W, Marinis JM, Beal AM, Savadkar S, Wu Y, Khan M, Taunk PS, Wu N, Su W, Wu J, et al. 2018. RIP1 kinase drives macrophage-mediated adaptive immune tolerance in pancreatic cancer. Cancer Cell 34: 757-774.e7. doi:10 $.1016 /$ j.ccell.2018.10.006

Welz PS, Wullaert A, Vlantis K, Kondylis V, FernándezMajada V, Ermolaeva M, Kirsch P, Sterner-Kock A van Loo G, Pasparakis M. 2011. FADD prevents RIP3mediated epithelial cell necrosis and chronic intestinal inflammation. Nature 477: 330-334. doi:10.1038/na ture10273

Wong WW, Vince JE, Lalaoui N, Lawlor KE, Chau D, Bankovacki A, Anderton H, Metcalf D, O'Reilly L, Jost PJ, et al. 2014. cIAPs and XIAP regulate myelopoiesis through cytokine production in an RIPK1- and RIPK3-dependent manner. Blood 123: 2562-2572. doi:10.1182/blood-201306-510743
Wu CJ, Conze DB, Li T, Srinivasula SM, Ashwell JD. 2006. Sensing of Lys 63-linked polyubiquitination by NEMO is a key event in NF- $\kappa B$ activation. Nat Cell Biol 8: 398-406. doi:10.1038/ncb1384

Wu J, Huang Z, Ren J, Zhang Z, He P, Li Y, Ma J, Chen W, Zhang Y, Zhou X, et al. 2013. Mlkl knockout mice demonstrate the indispensable role of Mlkl in necroptosis. Cell Res 23: 994-1006. doi:10.1038/cr.2013.91

Wu XN, Yang ZH, Wang XK, Zhang Y, Wan H, Song Y, Chen X, Shao J, Han J. 2014. Distinct roles of RIP1-RIP3 hetero- and RIP3-RIP3 homo-interaction in mediating necroptosis. Cell Death Differ 21: 1709-1720. doi:10 1038/cdd.2014.77

Xie T, Peng W, Yan C, Wu J, Gong X, Shi Y. 2013. Structural insights into RIP3-mediated necroptotic signaling. Cell Rep 5: 70-78. doi:10.1016/j.celrep.2013.08.044

Xu C, Wu X, Zhang X, Xie Q, Fan C, Zhang H. 2018a. Embryonic lethality and host immunity of RelA-deficient mice are mediated by both apoptosis and necroptosis. J Immunol 200: 271-285. doi:10.4049/jimmunol .1700859

Xu D, Jin T, Zhu H, Chen H, Ofengeim D, Zou C, Mifflin L, Pan L, Amin P, Li W, et al. 2018b. TBK1 suppresses RIPK1-driven apoptosis and inflammation during development and in aging. Cell 174: 1477-1491.e19. doi:10 .1016/j.cell.2018.07.041

Yamaguchi N, Yamaguchi N. 2015. The seventh zinc finger motif of A20 is required for the suppression of TNF- $\alpha$ induced apoptosis. FEBS Lett 589: 1369-1375. doi:10 $.1016 /$ j.febslet.2015.04.022

Yeh WC, de la Pompa JL, McCurrach ME, Shu HB, Elia AJ, Shahinian A, Ng M, Wakeham A, Khoo W, Mitchell K, et al. 1998. FADD: Essential for embryo development and signaling from some, but not all, inducers of apoptosis Science 279: 1954-1958. doi:10.1126/science.279.5358 .1954

Yeh WC, Itie A, Elia AJ, Ng M, Shu HB, Wakeham A, Mirtsos C, Suzuki N, Bonnard M, Goeddel DV, et al. 2000 Requirement for Casper (c-FLIP) in regulation of death receptor-induced apoptosis and embryonic development. Immunity 12: 633-642. doi:10.1016/S1074-7613 (00)80214-9

Zhang DW, Shao J, Lin J, Zhang N, Lu BJ, Lin SC, Dong MQ, Han J. 2009. RIP3, an energy metabolism regulator that switches TNF-induced cell death from apoptosis to necrosis. Science 325: 332-336. doi:10.1126/science .1172308

Zhang H, Zhou X, McQuade T, Li J, Chan FK, Zhang J. 2011. Functional complementation between FADD and RIP1 in embryos and lymphocytes. Nature 471: 373-376. doi:10 .1038/nature09878

Zhang J, Clark K, Lawrence T, Peggie MW, Cohen P. 2014. An unexpected twist to the activation of IKK $\beta$ TAK1 primes IKK $\beta$ for activation by autophosphorylation. Biochemical J 461: 531-537. doi:10.1042/BJ 20140444

Zhang X, Fan C, Zhang H, Zhao Q, Liu Y, Xu C, Xie Q, Wu X, Yu X, Zhang J, et al. 2016. MLKL and FADD are critical for suppressing progressive lymphoproliferative disease and activating the NLRP3 inflammasome. Cell Rep 16: 3247-3259. doi:10.1016/j.celrep.2016.06.103 
RIPK1 Regulates Cell Death and Inflammation

Zhang Q, Lenardo MJ, Baltimore D. 2017. 30 years of NF- $\mathrm{B}$ : A blossoming of relevance to human pathobiology. Cell 168: 37-57. doi:10.1016/j.cell.2016.12 .012

Zhang X, Dowling JP, Zhang J. 2019a. RIPK1 can mediate apoptosis in addition to necroptosis during embryonic development. Cell Death Dis 10: 245. doi:10.1038/ s41419-019-1490-8

Zhang S, Su Y, Ying Z, Guo D, Zou Z, Wang L, Zhang Z, Jiang Z, Zhang Z, Wang X. 2019b. RIP1 kinase inhibitor halts the progression of an immune-induced demyelination disease at the stage of monocyte elevation. Proc
Natl Acad Sci 116: 5675-5680. doi:10.1073/pnas .1819917116

Zhao J, Jitkaew S, Cai Z, Choksi S, Li Q, Luo J, Liu ZG. 2012. Mixed lineage kinase domain-like is a key receptor interacting protein 3 downstream component of TNF-induced necrosis. Proc Natl Acad Sci 109: 5322-5327. doi:10.1073/ pnas. 1200012109

Zinngrebe J, Rieser E, Taraborrelli L, Peltzer N, Hartwig T, Ren H, Kovács I, Endres C, Draber P, Darding M, et al. 2016. LUBAC deficiency perturbs TLR3 signaling to cause immunodeficiency and autoinflammation. J Exp Med 213: 2671-2689. doi:10.1084/jem.20160041 


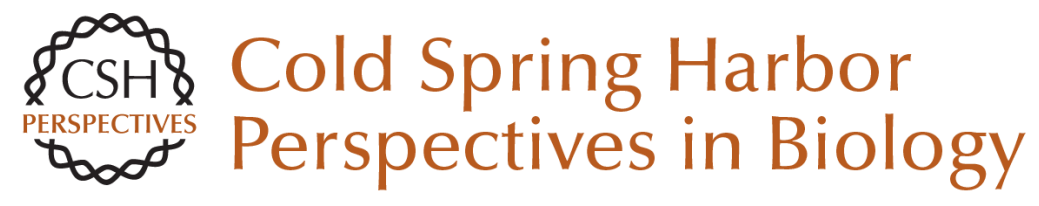

\section{Multitasking Kinase RIPK1 Regulates Cell Death and Inflammation}

Kim Newton

Cold Spring Harb Perspect Biol 2020; doi: 10.1101/cshperspect.a036368 originally published online August 19, 2019

\section{Subject Collection Cell Survival and Cell Death}

Programmed Cell Death in the Evolutionary Race against Bacterial Virulence Factors

Carolyn A. Lacey and Edward A. Miao

The Evolutionary Origins of Programmed Cell

Death Signaling

Kay Hofmann

Regulation of Cell Death and Immunity by XIAP Philipp J. Jost and Domagoj Vucic

Dysregulation of Cell Death in Human Chronic Inflammation

Yue Li, Christoph Klein and Daniel Kotlarz

Cell Death in Plant Immunity

Eugenia Pitsili, Ujjal J. Phukan and Nuria S. Coll

Recent Insights on Inflammasomes, Gasdermin

Pores, and Pyroptosis

Nathalia M. de Vasconcelos and Mohamed Lamkanfi

Phagocyte Responses to Cell Death in Flies Andrew J. Davidson and Will Wood

Mechanism and Regulation of

Gasdermin-Mediated Cell Death

Shiyu Xia, Louis Robert Hollingsworth IV and Hao Wu
Cell Death and Neurodegeneration Benjamin J. Andreone, Martin Larhammar and Joseph W. Lewcock

Death Receptors and Their Ligands in Inflammatory Disease and Cancer Alessandro Annibaldi and Henning Walczak

The Killer Pseudokinase Mixed Lineage Kinase Domain-Like Protein (MLKL) James M. Murphy

Neutrophil Extracellular Traps in Host Defense Sabrina Sofia Burgener and Kate Schroder

Cell-Cycle Cross Talk with Caspases and Their Substrates

Patrick Connolly, Irmina Garcia-Carpio and Andreas Villunger

Cracking the Cell Death Code Carla V. Rothlin and Sourav Ghosh

BAX, BAK, and BOK: A Coming of Age for the BCL-2 Family Effector Proteins Tudor Moldoveanu and Peter E. Czabotar

Multitasking Kinase RIPK1 Regulates Cell Death and Inflammation Kim Newton

For additional articles in this collection, see http://cshperspectives.cshlp.org/cgi/collection/

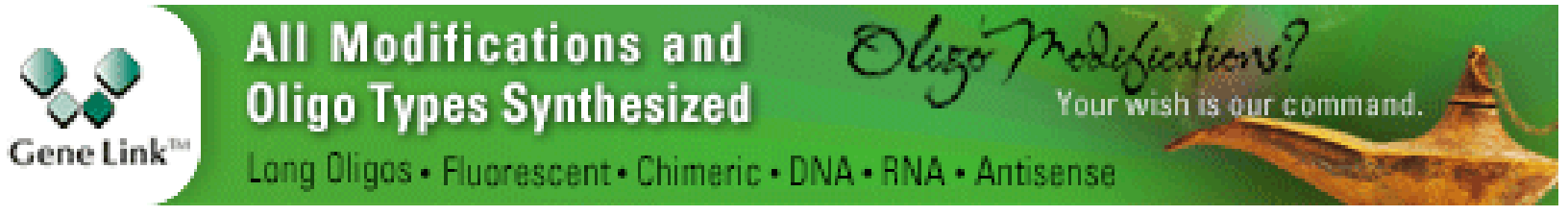


For additional articles in this collection, see http://cshperspectives.cshlp.org/cgi/collection/

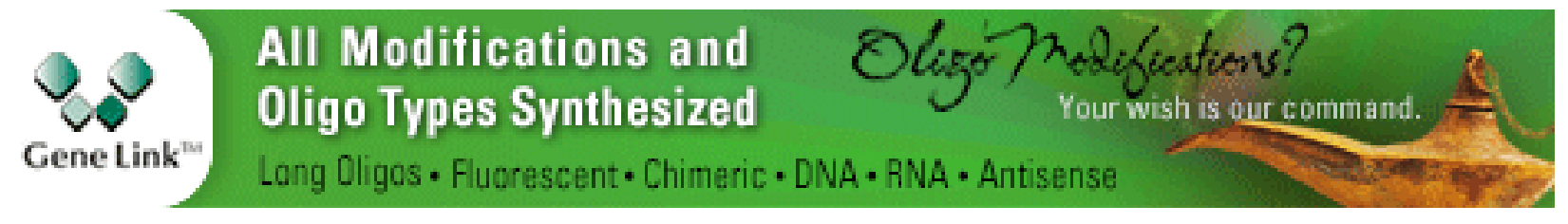

Copyright @ 2020 Cold Spring Harbor Laboratory Press; all rights reserved 